\title{
Invertebrate trace fossils from the Pennsylvanian Rhode Island Formation of Massachusetts, USA
}

\author{
Patrick R. Getty ${ }^{1}$, Robert Sproule ${ }^{2}$, Matthew R. Stimson ${ }^{3}$, And Paul C. Lyons ${ }^{4}$ \\ 1. Center for Integrative Geosciences, University of Connecticut, 354 Mansfield Road, Storrs, Connecticut 06269, USA \\ 2. 40 Paulette Terrace, Plymouth, Massachusetts 02360, USA \\ 3. Steinhammer Palaeontology Laboratory, Natural Science Department, New Brunswick Museum, \\ Saint John, New Brunswick E2K 1E5, Canada \\ 4. 206 Amber Road, Middleboro, Massachusetts, USA \\ *Corresponding author <patrick.getty@uconn.edu>
}

Date received: 15 November 2016 Date accepted: 03 January 2017

\begin{abstract}
A large open-pit quarry in Plainville, Massachusetts, has yielded fourteen invertebrate ichnotaxa from the Pennsylvanian Rhode Island Formation of the Narragansett Basin. These traces include Cochlichnus anguineus, Diplichnites cuithensis, Diplichnites gouldi, Diplopodichnus biformis, Gordia carickensis, Helminthoidichites tenuis, Lockeia isp., Mitchellichnus cf. ferrydenensis, Planolites montanus, Siskemia elegans, Stiallia pilosa, Stiaria intermedia, Tonganoxichnus buildexensis and Narragansettichnus fortunatus new ichnogenus and ichnospecies. Specimens were collected from talus and the depositional environment has been inferred from sedimentary structures. The sedimentology of the slabs on which the traces were preserved indicates that the rocks represent lake-margin and shallow lacustrine sedimentary facies. Distinct ichnofacies occur in the different sedimentary environments. The lake-margin traces belong to the Scoyenia ichnofacies and include traces of apterygote insects, arthropleurid myriapods, bivalved arthropods and vermiform animals in association with tracks of temnospondyl amphibians and diapsid reptiles. The lacustrine traces include arthropod trackways, fish trails and a newly named body imprint possibly produced by an aquatic mayfly larva. These shallow lacustrine traces are attributed to the Mermia ichnofacies.
\end{abstract}

\section{RÉSUMÉ}

Une vaste carrière à ciel ouvert à Plainville, Massachusetts, a mis au jour 14 ichnotaxons invertébrés de la formation du Rhode Island de la période pennsylvanienne dans le bassin de Narragansett. Les traces relevées comprennent Cochlichnus anguineus, Diplichnites cuithensis, Diplichnites gouldi, Diplopodichnus biformis, Gordia carickensis, Helminthoidichites tenuis, Lockeia isp., Mitchellichnus cf. ferrydenensis, Planolites montanus, Siskemia elegans, Stiallia pilosa, Stiaria intermedia et Tonganoxichnus buildexensis, et le nouveau ichnogenre et ichnoespèces Narragansettichnus fortunatus. Les spécimens ont été prélevés d'un talus et le milieu de sédimentation a été déduit à partir de structures sédimentaires. La sédimentologie des plaques sur lesquelles les traces ont été conservées révèle que les roches représentent un faciès sédimentaire caractéristique des marges lacustres et des eaux lacustres peu profond. Des ichnofaciès distincts sont présents dans les différents milieux sédimentaires. Les traces riveraines font partie de l'ichnofaciès Scoyenia et comprennent des traces d'insectes aptérygotes, de myriapodes arthropleurides, d'arthropodes bivalvés et d'animaux vermiformes associées à des pistes d'amphibiens temnospondyles et de reptiles diapsides. Les traces lacustres comprennent des tracés d'arthropodes, des pistes de reptation de poissons et une empreinte d'organisme nouvellement baptisé possiblement produite par une larve d'éphémère commune aquatique. Ces traces lacustres peu profondes sont rattachées à l'ichnofaciès Mermia.

[Traduit par la redaction]

\section{INTRODUCTION}

Over a century ago, when Woodworth (1900) described the first vertebrate tracks from the Narragansett Basin, he noted the depauperate state of knowledge of Carbonifer- ous ichnofaunas from New England in comparison to those described from elsewhere, such as the Maritime Provinces of Canada and farther south in the Appalachians. In the intervening century, only a few additional papers (e.g., Lull 1920; Willard and Cleaves 1930) were published on a rela- 
tively small number of specimens from New England, so few that Lucas (2007) considered the tetrapod track record of the region to be "scattered". Rather than being the result of a scarcity of trace fossils, however, the dearth of ichnological studies in the Narragansett Basin most likely results from the rocks being inaccessible due to vegetation and urban sprawl, as well as from them being tectonically overprinted, which distorts and obscures the tracks (Fichman et al. 2015). Recently there has been a resurgence in the study of vertebrate trace fossils in the Narragansett Basin (Getty et al. 2010; Knecht and Benner 2008; Knecht et al. 2009; Sproule and Getty 2012), which will help to illuminate the ichnofaunas from the New England region.

Although our understanding of Narragansett Basin's Carboniferous vertebrate ichnofaunas is rudimentary, our understanding of invertebrate ichnofaunas from New England is even poorer. To our knowledge, Packard (1900a, b), who described three arthropod trackways and some "worm holes", remained the only researcher to report invertebrate traces from this region until over a century later, when Knecht et al. (2011) described a body imprint that they attributed to a winged insect. A lively debate has since ensued about the origin of Knecht et al.'s (2011) body imprint (Marden 2013a, b; Benner et al. 2013). In another recent paper, Getty et al. (2013) described a suite of insect trackways and body imprints from the Rhode Island Formation. The morphology of some of the trackways is unusual, which led the authors to experiment with modern insects to try to identify the behaviors that made the fossils. The meager publication record emphasizes how little has been done, but the research by Knecht et al. (2011) and Getty et al. (2013) shows that new and important discoveries are possible. In this contribution, we describe a suite of invertebrate trace fossils from the Rhode Island Formation of Massachusetts, which contributes to a more complete regional picture of invertebrate ichnofaunas from Pennsylvanian lake and lake margin environments.

\section{GEOLOGICAL CONTEXT}

The Narragansett Basin (Fig. 1) is an intermontane rift basin that filled with fluvial and lacustrine sediments that produced conglomerate, sandstone, siltstone, shale and coal (Shaler et al. 1899; Mutch 1968). Depositional environments were varied, including well-drained intermontane alluvial fans, braided to low-energy meandering streams, floodplains, lakes and swamps, and ephemeral ponds and pools (Mosher 1983 and references therein; Knecht et al.

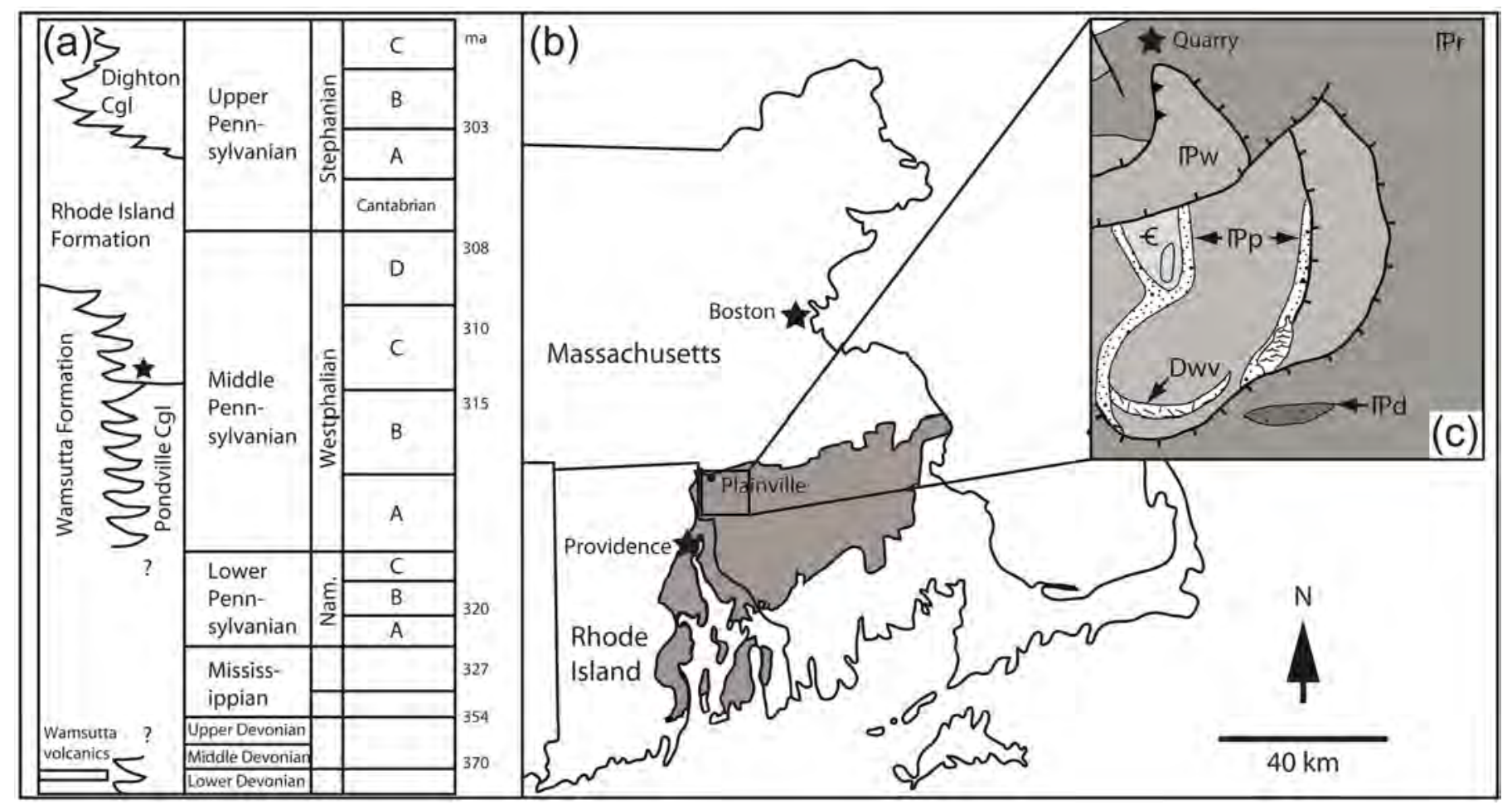

Figure 1. Stratigraphic and geologic context of the fossils described in this paper. (a) Stratigraphy of the Narragansett Basin. Column modified from Skehan et al. (1979), with data from Maria and Hermes (2001) and Thompson and Hermes (2003). The approximate position of the fossil locality is indicated by a star. (b) Map of southeastern New England highlighting the Narragansett Basin. (c) Bedrock geology around Plainville, Massachusetts. Map modified from Zen et al. (1983). Abbreviations: $€=$ Cambrian inliers; $\mathrm{Cgl}=$ conglomerate; $\mathrm{Dwv}=$ Wamsutta volcanics; Nam. $=$ Namurian; ${ }^{\star} \mathrm{d}=$ Dighton Conglomerate; ${ }^{\star} \mathrm{p}=$ Pondville Conglomerate; ${ }^{\star} \mathrm{r}=$ Rhode Island Formation; ${ }^{\star} \mathrm{w}=$ Wamsutta Formation. 
2011). Sediment supply for the Narragansett Basin, as determined by Towe (1959), was from the northeast. The exact timing of the formation of the basin is subject to continued research. Mosher (1983) suggested that it formed as two smaller, differentially deformed, composite grabens coalesced during the collision of Avalonia with Laurentia, whereas Maria and Hermes (2001) and Thompson and Hermes (2003) suggest that crustal extension began in the Late Devonian.

Shaler et al. (1899) were the first to map and describe the rocks of the Narragansett Basin; Skehan and Murray (1978) modified their observations. Formations within the basin are, from oldest to youngest, the Pondville Conglomerate, Wamsutta Formation, Rhode Island Formation and the Dighton Conglomerate (Fig. 1a). The Pondville Conglomerate is arkosic to quartz- and quartzite-pebble rich; it has interbedded red and green shale and siltsone of Westphalian A/B (Langsettian/Duckmantian) age. The overlying Wamsutta Formation is a fluvial red-bed series that is assigned an upper-Westphalian B (upper-Langsettian)/lowerWestphalian B (lower Duckmantian) age in the vicinity of North Attleboro, based on Knox (1944) and the unpublished work of R.S. and P.C.L. The Wamsutta Formation is composed of conglomerates, sandstones, siltstones, shales, and calcareous beds, the last of which are associated with felsic volcanic rocks and diabases (Foerste in Shaler et al. 1899). The Rhode Island Formation will be described below. The Dighton Conglomerate is composed of well-roundedquartz and quartzite-pebble conglomerate with sandstone (Shaler et al. 1899). To date no biostratigraphically useful fossils have been found in the Dighton Conglomerate and its age is inferred from its stratigraphic relationship with the Rhode Island Formation.

The Rhode Island Formation, from which the fossils described herein come, is by far the thickest formation in the Narragansett Basin. In some areas, it interfingers with the Wamsutta Formation (Shaler et al. 1899). An abundant, highly diverse fossil flora found throughout the formation reveals that the Rhode Island Formation extends from Westphalian C (Bolsovian) to Stephanian B/C times (Lyons and Darrah 1978; Lyons 1984; Wagner and Lyons 1997). Sediments are fluvial and lacustrine, comprising grey- to red-pebble conglomerates, laminated and cross-bedded sandstones, siltstones, and shales occasionally interbedded with coal (Shaler et al. 1899). With a few notable exceptions, Rhode Island Formation coals are impure (Lyons and Chase 1981).

The invertebrate trace fossils discussed herein were collected from a large, open-pit quarry in Plainville, Massachusetts (Figs. 1b-c), the walls of which display folded beds of sandstone, shale and coal that were deformed and metamorphosed to lower greenschist facies in the Late Stephanian or Permian (ca. 290-280 Ma) during the Alleghanian Orogeny (Lyons and Chase 1976; Skehan et al. 1979; Dallmeyer 1982; Mosher 1983; Lyons 1984; Murray et al. 2004; Lynn and Krol 2006). North-south anticlines produced by east-west compression are seen in the walls of the pit, with axial planes dipping to the northwest (Skehan et al. 1979; Mosher 1983). Shales within the quarry have been interpreted as being deposited in low-energy interchannel swamp and floodplain settings (Towe 1959; S. Voigt, personal communication, 2010); mud rip-up clasts, derived from intraformational shales, demonstrate local erosion, and preferred orientations of plant axes show drainage from the northeast. Sedimentary structures associated with the fossils include asymmetrical current ripples, raindrop imprints, desiccation cracks, and gas-escape structures. Commingled with the invertebrate trace fossils are abundant vertebrate ichnites, including: Batrachichnus and Characichnos, which were produced by temnospondyl amphibians; Notalacerta, which was produced by diapsid reptiles; and Undichna, which was produced by fish (Getty et al. 2010). Tectonic strain has altered the shape of the fossils found in the quarry, but a recent retrodeformation study by Fichman et al. (2015) provides a method by which accurate measurements can be obtained.

The quarry has been dated using an extensive flora of 23 taxa (Appendix A), as modified from Oleksyshyn (1976). The age of the flora is Bolsovian (Westphalian C). A flora previously collected from the same site as the trace fossils belongs to the Bolsovian Alethopteris serlii subzone of the British Coal Measures (Cleal 1994).

\section{MATERIALS AND METHODS}

The specimens described herein were collected from talus piles at the base of the quarry walls, formed during blasting. Consequently, none of the specimens were found in situ and details of their stratigraphic placement within the quarry are meager. The lack of stratigraphic control makes inferring trace fossil associations and establishing ichnofacies difficult, especially since most of the fossilbearing slabs are small and consequently preserve only a few traces each. As will be discussed later, the lithology of the fossil-bearing slabs was used to partly overcome this problem.

The specimens are now housed at the Springfield Science Museum (abbreviated SSM) in Springfield, Massachusetts, and in the Invertebrate Paleontology Division of the Peabody Museum of Natural History at Yale University (abbreviated YPM-IP). Details about the locality may be obtained from either of these institutions. YPM numbers have six digits and refer to individual specimens, whereas SSM numbers are fractional, include a hyphenated denominator, and refer to the slabs on which the specimens are preserved. The fossils were photographed with a Nikon Coolpix L18 or Canon EOS 7D camera, and measurements were taken from the photographs using ImageJ software (Rasband 1997-2014). 


\section{SYSTEMATIC ICHNOLOGY}

\section{Ichnogenus Cochlichnus Hitchcock 1858}

Cochlichnus anguineus Hitchcock 1858

(Fig. 2)

1858 Cochlichnus anguineus Hitchcock, p. 161, pl. 26, fig. 6 .

MATERIAL: A single specimen preserved on SSM 2015/3-12.

DESCRIPTION: This trace is a $2.8 \mathrm{~cm}$ long sinusoidal surface trail with a shallow, u-shaped cross-sectional profile and a variable width ranging from 1.3 to $3.0 \mathrm{~mm}$. The wavelength ranges from 16.9 to $17.7 \mathrm{~mm}$ and the amplitude from 4.0 to $6.1 \mathrm{~mm}$. The waveforms produced by the trail are asymmetric; that is, they are longer on one side of the trace than the other. There are small rims of sediment paralleling the sides of the trail in some places.

OCCURRENCE: The specimen occurs on a slab composed of alternating layers of light- and dark-grey siltstone with Diplichnites gouldi trackways preserved on laminae both above and below.

REMARKS: Hitchcock (1858) established Cochlichnus anguineus for sinusoidal trails from the Early Jurassic Turners Falls Formation in Massachusetts. The trace is considered a grazing trail and is often attributed to insect larvae, nematodes and annelid worms (Metz 1988, and references therein).

Cochlichnus anguineus can be confused with another sinusoidal trail called Undichna unisulca, which is attributed to fish (de Gilbert et al. 1999). The two ichnospecies can be differentiated, however, in that Cochlichnus anguineus has a smaller amplitude and wavelength, and is less sharply incised than Undichna unisulca (de Gilbert et al. 1999; Morrissey et al. 2004; Minter and Braddy 2006a). Minter and Braddy (2006a), however, noted that the size distinction between the two ichnotaxa is not always straightfor-

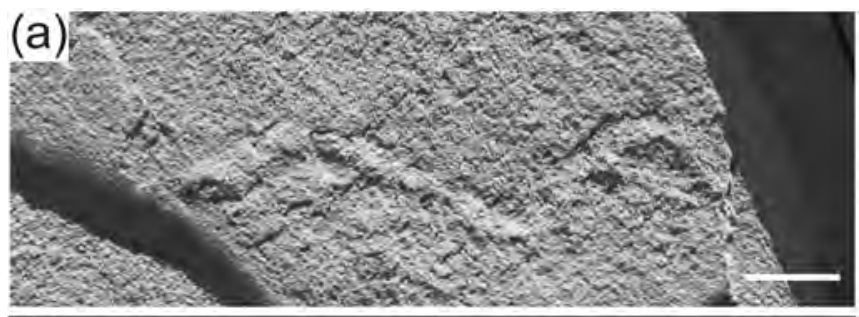

(b)

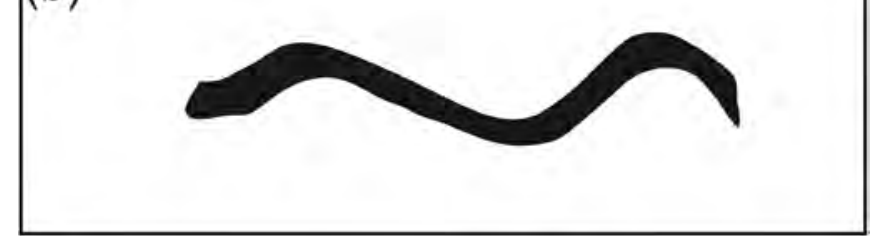

Figure 2. Photograph (a), and interpretive drawing (b), of Cochlichnus anguineus on SSM 2015/3-12. Scale bar is $5 \mathrm{~mm}$. ward and that the primary differentiating feature between the two ichnotaxa is how sharply the traces are incised. The present specimen has a smaller amplitude and wavelength than sharply incised traces from the same quarry that have been assigned to Undichna unisulca. It also has a shallow, $\mathrm{u}$-shaped bottom. For these reasons the specimen is here assigned to Cochlichnus anguineus.

\section{Ichnogenus Diplichnites Dawson 1873}

Diplichnites cuithensis Briggs et al. 1979

(Fig. 3)

1979 Diplichnites cuithensis Briggs et al., p. 289, pl. 28-30.

1988 Diplichnites minimus; Walter and Gaitzsch, p. 75, tables 1-3.

MATERIAL: Nine specimens on slabs SSM 2015/3-1 through SSM 2015/3-8, and a partial trackway on SSM 2015/3-25. The counterpart to SSM 2015/3-25 is YPM IP 236963.

DESCRIPTION: Diplichnites cuithensis is a trackway composed of two parallel rows of tracks, specimens of which vary in scale from diminutive trackways with inner and outer widths of $2.3 \mathrm{~mm}$ and $4.0 \mathrm{~mm}$ (Figs. 3a-d) to much larger trackways with inner and outer widths of $30.1 \mathrm{~mm}$ and $44.5 \mathrm{~mm}$ (Figs. 3e-f). The track rows, which measure from 0.4 to $6.6 \mathrm{~mm}$ wide, are narrow relative to the overall trackway width. The track rows vary in the number of tracks along their preserved length. The number of tracks per track row series is unknown, but given the density of footprints along the track rows, the number is assumed to be quite high. One small trackway (Figs. 3a-b) exhibits series of at least five tracks, but a complete track row series count is impossible because the trackway is overstepped by another one. Another small trackway (Figs. 3c-d) exhibits a false series of three tracks in a track row series. Track morphologies are similar for both small and large varieties of the ichnospecies; individual tracks are small and circular, elliptical, ovate, or teardrop-shaped in plan view. The long axes of ovate and teardrop-shaped tracks are oblique to nearly perpendicular to the long axis of the trackway. Tracks are more widely spaced in larger trackways such that the position of tracks within the rows allows for significant overlap in the track row series (Figs. 3e-f). By contrast, in smaller trackways the individual tracks are often so closely spaced that they are often difficult to distinguish. Medial imprints are absent.

OCCURRENCE: The slabs on which the trackways occur include fine-grained, muddy sandstone or light-grey shale/ mudstone. Associated sedimentary structures include oscillation ripple marks, raindrop imprints, gas-escape structures and desiccation cracks. Associated trace fossils include tetrapod tracks assigned to the ichnogenus Batrachichnus (Fig. 3e), which is attributed to temnospondyl amphibians (e.g., Haubold 1970, 1971), as well as possible rhizoliths. 

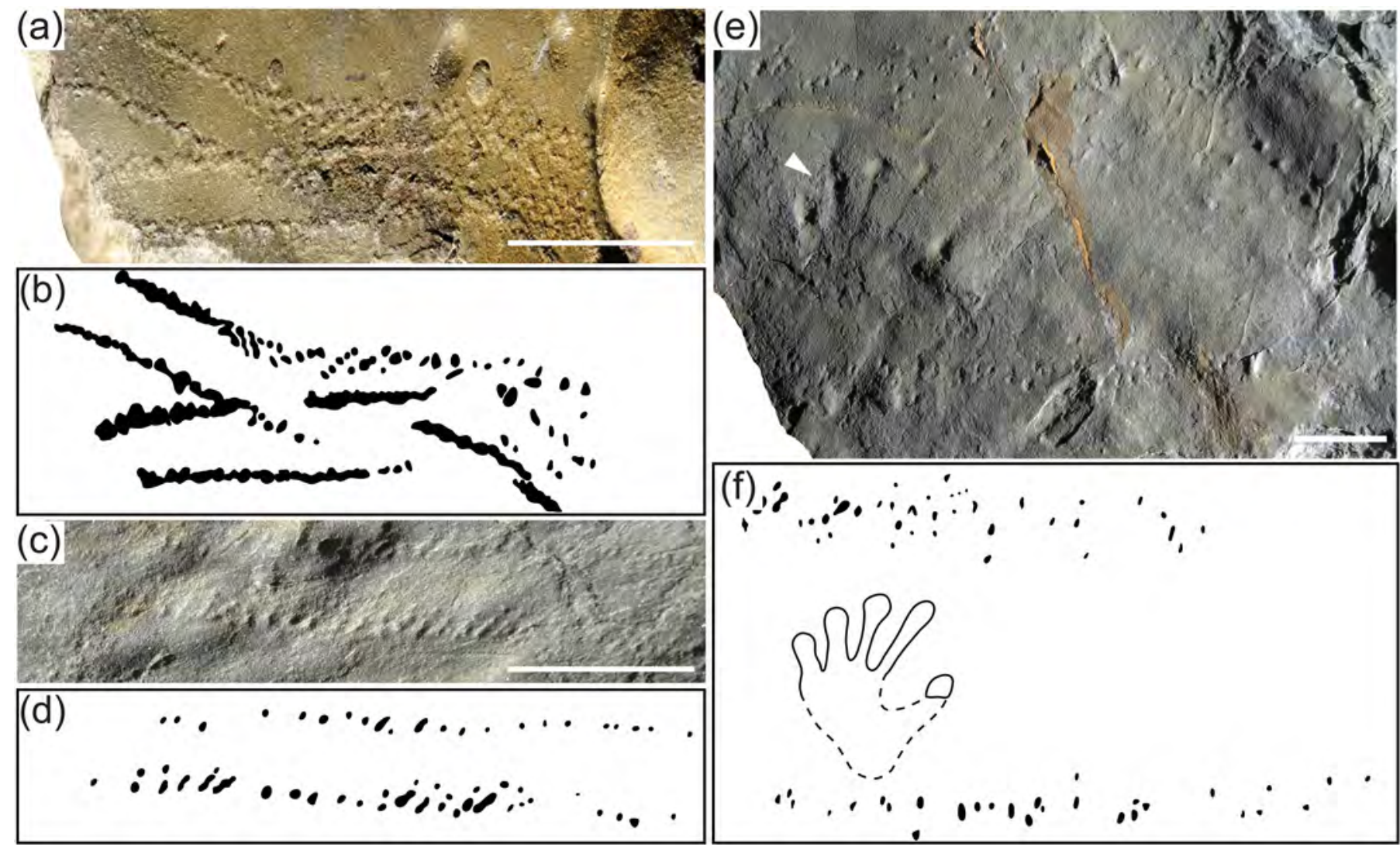

Figure 3. Diplichnites cuithensis trackways from the Pennsylvanian Rhode Island Formation of Massachusetts. Photograph (a) and interpretive drawing (b) of SSM 2015/3-3, which exhibits two overlapping trackways. Photograph (c) and interpretive drawing (d) of SSM 2015/3-4, which exhibits a trackway with false series of three tracks. Photograph (e) and interpretive drawing (f), SSM 2015/3-8. Note the Batrachichnus pes track (arrowed) within the trackway in (e). All scale bars are $10 \mathrm{~mm}$.

REMARKS: The ichnogenus Diplichnites and its type species, Diplichnites aenigma, were erected by Dawson (1873) from Coal Mine Point, Joggins, Nova Scotia, Canada. Unfortunately, Dawson's type specimen has not been located, no replicas are known, and the ichnogenus is badly in need of revision. Briggs et al. (1979) established the ichnospecies Diplichnites cuithensis for large (up to $36 \mathrm{~cm}$ wide) Diplichnites trackways from the Carboniferous of Scotland and attributed the trackways to arthropleurid myriapods, specifically Arthropleura, the largest known terrestrial arthropod. Since then, additional large arthropleurid trackways have been found in numerous localities in Europe and North America (as summarized in Schneider et al. 2010). Walter and Gaitzsch (1988) described morphologically similar, but much smaller (2.8 to $4.0 \mathrm{~cm}$ wide) trackways from Germany as Diplichnites minimus. Considering that size is generally not considered a valid ichnotaxobase (Bertling et al. 2006; Buatois and Mángano 2011), Schneider et al. (2010) argued that Diplichnites minimus should be considered a junior subjective synonym of Diplichnites cuithensis, an assessment that we follow here.

The largest Diplichnites cuithensis described from this site are small compared to those described from other Pennsyl- vanian and Permian localities, which can reach up to $50 \mathrm{~cm}$ wide (Ryan 1986). Such small Diplichnites cuithiensis can be distinguished from other small Diplichnites, for example Diplichnites gouldi, on the basis of the number of tracks in a track row series. Diplichnites gouldi typically has up to 7 tracks in a track row series, whereas Diplichnites cuithiensis has up to 23 tracks in a series, the latter corresponding to the number of walking appendages of an Arthropleura (Trewin and McNamara 1994). Since the specimens described herein show a remarkable similarity to some specimens (e.g., table III, fig. 3) of Diplichnites cuithensis figured by Walter and Gaitzsch (1988), we assign the Massachusetts specimens to that ichnospecies. Although commonly of colossal size, up to two metres long, arthropleurid body fossils as small as one centimetre long are known (Briggs and Almond 1994; Perrier and Charbonnier 2014). Thus, it is not unreasonable to attribute small Diplichnites cuithensis to arthropleurids, as we do here.

Getty et al. (2013, figs. 3E-F) incorrectly interpreted YPM IP 236963 as a Stiaria intermedia trackway. The trackway is actually two separate fossils - a partial Diplichnites cuithensis trackway and Gordia carickensis trail. 
Diplichnites gouldi Gevers in Gevers et al. 1971 (Fig. 4)

1971 Diplichnites gouldi Gevers in Gevers et al., p. 86, pl. 19, figs. 2-4.

MATERIAL: Numerous specimens on slabs SSM 2015/3-9 through SSM 2015/3-19.

DESCRIPTION: Trackways composed of two simple rows of well-spaced tracks with outer widths ranging from 1.1 to $3.7 \mathrm{~cm}$. In all but one trackway (Figs. 4a-b), the track rows are composed of discrete series of six tracks. The series have a preserved length ranging from 1.6 to $4.6 \mathrm{~cm}$ and are oriented at an angle of $10^{\circ}$ to $20^{\circ}$ relative to the trackway axis. Track rows measure from 0.4 to $1.2 \mathrm{~cm}$ wide, depending on the width of the individual tracks and the orientation of the series relative to the trackway axis. Overlap among the series, where present, ranges from $0.2 \mathrm{~cm}$ to $1.0 \mathrm{~cm}$. Strides range from 1.4 to $3.0 \mathrm{~cm}$. Individual tracks are elongate and straight, or comma-shaped to semilunate in plan view, with their long axes oriented oblique to trackway midlines. Comma-shaped tracks can either taper internally or externally. The interseries distance ranges from $0.3 \mathrm{~cm}$ to $1.0 \mathrm{~cm}$. Medial imprints are absent.

OCCURRENCE: SSM 2015/3-9 through 2015/3-18 are composed of laminated, light- to dark-grey siltstone. Some slabs, such as SSM 2015/3-11, exhibit a distinct pinstripe pattern to the laminae. Another slab, SSM 2015/3-17, exhibits cross bedding. Sedimentary structures such as raindrop imprints, gas-escape structures and desiccation cracks, common on other slabs, are absent from these slabs. Associated trace fossils include the fish swimming trace Undichna unisulca (Figs. $4 \mathrm{~g}-\mathrm{h}$ ), and the invertebrate trail Cochlichnus anguineus. A single slab, SSM 2015/3-19, exhibits undulating mud to silt laminae, mudcracks, possible ripples and Batrachichnus tracks.

REMARKS: Diplichnites gouldi was erected as Arthropodichnus gouldi by Gevers in Gevers et al. (1971). Later, recognizing that Arthropodichnus gouldi was a junior homonym for morphologically different traces, Gevers (1973) reassigned all of his previously named Arthropodichnus species to the new ichnogenus Beaconichnus. Bradshaw (1981) redescribed Gevers specimens and synonymized all other ichnospecies with Diplichnites gouldi. Many authors have divided Diplichnites gouldi into discrete morphotypes called Type A and Type B, and in one case Type C (Trewin and McNamara 1994; Minter et al. 2007a). Lucas et al. (2006) noted that many specimens assigned to Diplichnites gouldi strongly resemble other Diplichnites species (e.g., Diplichnites triassicus) and that the ichnogenus and its included ichnospecies are in need of revision.

The specimens described here bear a strong resemblance
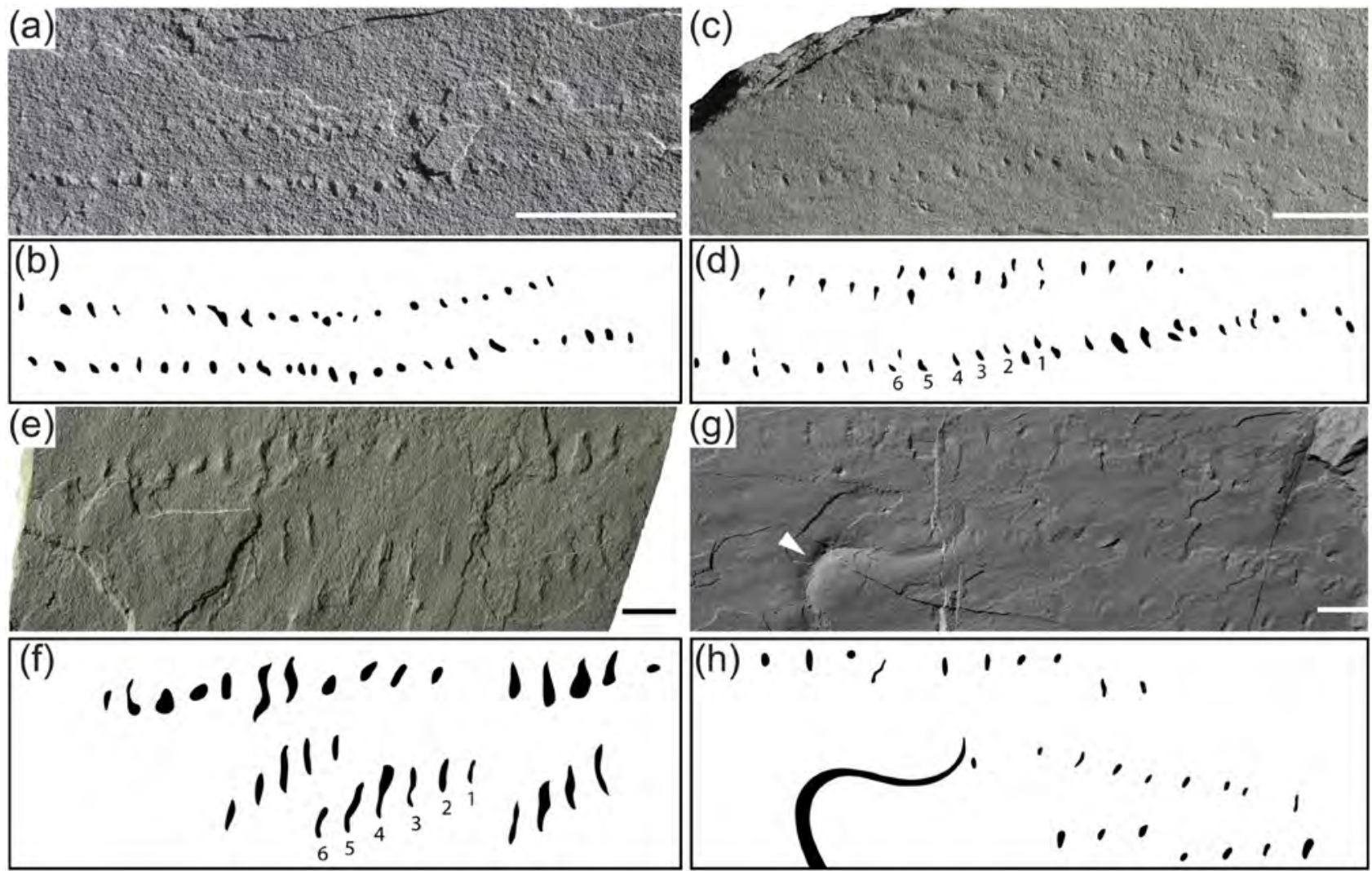

Figure 4. Diplichnites gouldi trackways from the Pennsylvanian Rhode Island Formation of Massachusetts. All trackways with discrete series are shown with the series widening to the left. Photograph (a) and interpretive drawing (b) of SSM 2015/3-16. Photograph (c) and interpretive drawing (d) of SSM 2015/3-13. Photograph(e) and interpretive drawing (f) of SSM 2015/3-11. Photograph (g) and interpretive drawing (h) of SSM 2015/3-10. Note the Undichna unisulca trail (arrowed) within the trackway in $(\mathrm{g})$. All scale bars are $10 \mathrm{~mm}$. 
to Acripes incertipes, which was reassigned to Diplichnites by Pickerill (1992). The only notable difference between the two ichnospecies is that Matthew (1910) described Diplichnites incertipes as being asymmetric, whereas Diplichnites gouldi is symmetric (Gevers in Gevers et al. 1971). Numerous factors, however, can influence the symmetry of a trackway, such as walking across inclined plains (e.g., Sadler 1993). Consequently, trackway symmetry could be considered a minor morphological gait variant, thus making it a poor ichnotaxabase. Reassessing the validity of these ichnospecies is beyond the scope of this paper, but such work may show that the two ichnotaxa are synonymous. The specimens described herein conform to the emended diagnoses provided by Buatois et al. (1998a) and Minter et al. (2007a) and resemble specimens described from ageequivalent strata by Prescott et al. (2014). Thus, we tentatively assign these traces to Diplichnites gouldi, pending further ichnotaxonomic revision.

This ichnospecies is attributed to a wide variety of arthropods depending on the age of the fossils and the environment in which they are preserved. Bradshaw (2010), for example, attributed her examples to trilobites, whereas Smith et al. (2003) attributed their examples to kampecarid myriapods and eoarthropleurids. Diplichnites gouldi also has been interpreted as the trackway of aquatic euthycarcinoids (Trewin and McNamara 1994), as well as crustaceans such as palaeocaridaceans, anaspidacean syncarids, mysidaceans and isopods (Minter et al. 2007a).

\section{Ichnogenus Diplopodichnus Brady 1947}

\section{Diplopodichnus biformis Brady 1947}

(Fig. 5)

1947 Diplopodichnus biformis Brady, p. 469, pl. 69, fig. 4.

MATERIAL: Four specimens preserved on three slabs, SSM 2015/3-20 through SSM 2015/3-22.

DESCRIPTION: Straight to slightly winding surface trails consisting of two subparallel to parallel grooves, between which is an area of undisturbed sediment. Ridges of disturbed sediment are present in one specimen outside the grooves. Grooves may retain the same thickness along their length, or they may vary in thickness. The grooves in parts of some trails (e.g., Fig. 5a, arrowed) are replaced by a series of discrete ovate imprints oriented obliquely to the long axis of the trace; other portions of these trails exhibit grooves with ovate impressions within them. Another specimen (Fig. 5b, arrowed) separates into a series of cuneiform marks laterally and oblique scratches medially such that one side of the trace resembles Dendroidichnites irregulare for a short distance. Trails range from 3.8 to $11.9 \mathrm{~mm}$ wide externally and $0.6 \mathrm{~mm}$ to $5.5 \mathrm{~mm}$ internally. Trails with subparallel grooves (Fig. 5c) increase in width by as much as $58 \%$ along their length. Preservation includes concave epirelief and convex hyporelief.
OCCURRENCE: The slabs on which these specimens are preserved are composed of laminated silt and mud. They are light grey on freshly broken surfaces, but most surfaces are highly oxidized from exposure. The surface of SSM 2015/3-21 is slightly undulatory, which may represent rippling on the bed surface. SSM 2015/3-20 preserves desiccation cracks on both its top and bottom, as well as a $\mathrm{Ba}$ trachichnus manus on its underside.

REMARKS: Brady (1947) established Diplopodichnus biformis for traces consisting of a double groove that he collected from the Coconino Sandstone of Arizona. As originally defined, this taxon is difficult to distinguish from Didymaulichnus, so Keighley and Pickerill (1996) emended the diagnosis such that Diplopodichnus biformis is now restricted to traces with grooves that are separated by a distance equal to or greater than one groove width. Brady's (1947) diagnosis is problematic also in that it stated that distinct foot imprints were absent, which would thus seem to preclude the Massachusetts material from Diplopodichnus biformis. Brady did note the presence of faint foot imprints in his description, however, and thus the presence of individual imprints in Diplopodichnus biformis is not a problem.

Brady (1947) considered the most likely producers of Diplopodichnus biformis to be millipedes, although he noted that small beetles make similar traces. Both field observations (e.g., Eiseman and Charney 2010) and laboratory experiments (Davis et al. 2007) confirm that modern millipedes produce Diplopodichnus-like traces.
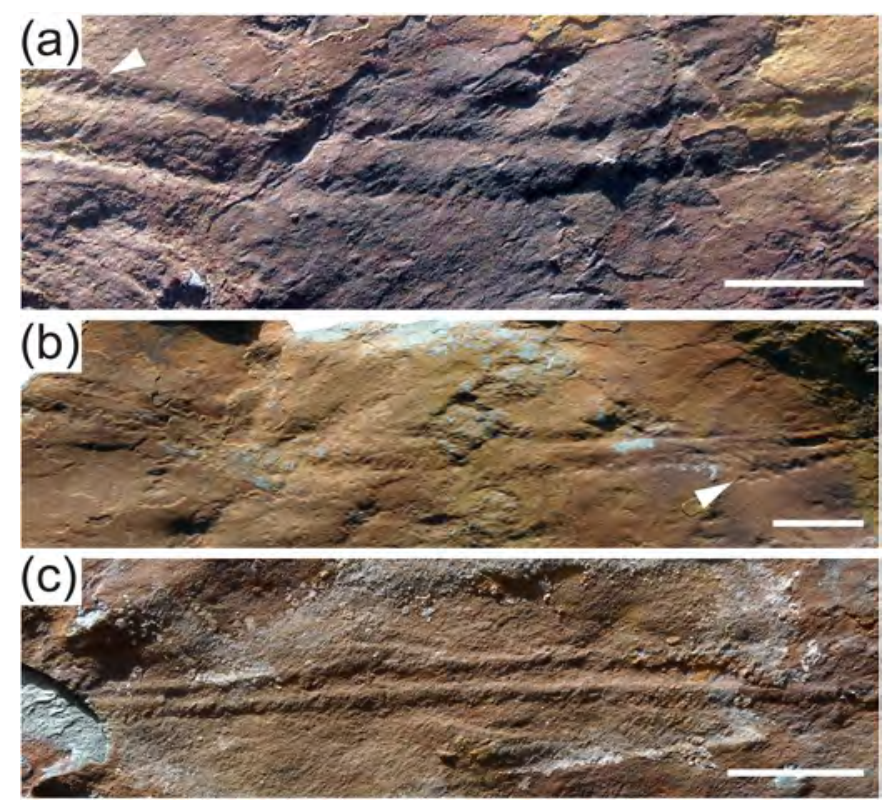

Figure 5. Diplopodichnus biformis trails from the Pennsylvanian Rhode Island Formation of Massachusetts. (a) SSM 2015/3-20. Note that the groove (arrowed) becomes a series of discrete ovate imprints oriented obliquely to the long axis of the trace in the upper left corner of the image. (b) SSM 2015/3-21. Note here that part of a groove (arrowed) separates into cuneiform marks and oblique scratches. (c) SSM 2015/3-22, showing a Diplopodichnus biformis that is narrower on the left than right. All scale bars are $10 \mathrm{~mm}$. 
Ichnogenus Gordia Emmons 1844

Gordia carickensis Smith 1909

(Fig. 6a)

1909 Gordia carickensis Smith, p. 25, fig. 43.

MATERIAL: Several specimens on SSM 2015/3-23 through SSM 2015/3-25. The latter specimen is the counterpart to YPM IP 236963.

DESCRIPTION: Uniformly thin $(0.2-0.3 \mathrm{~mm})$, unornamented, bedding plane-parallel, looping and self-crossing trails that are preserved as concave epireliefs or convex hyporeliefs. Individual loops measure up to $2.5 \mathrm{~cm}$ wide. Some trails are irregularly sinusoidal along their length, with low ( 0.1-0.3 mm), but rarely higher (up to $1.0 \mathrm{~mm}$ ) amplitude bends.

OCCURRENCE: The slabs on which these specimens are preserved are composed of light-grey mudstone. SSM 2015/3-24 splits into thin shaly layers and preserves, on its top, Characichnos isp. swim tracks, attributed to the Batrachichnus trace maker due to size. SSM 2015/3-25 is blocky. Both slabs preserve raindrop imprints and desiccation cracks.

REMARKS: The ichnogenus Gordia is similar to Helminthoidichnites and Helminthopsis, but can be differentiated from these two taxa by its tendency to loop and self-cross (e.g., Pickerill and Peel 1991; Han and Pickerill 1995; MacNaughton and Pickerill 1995; Buatois et al. 1998b; Uchman et al. 2009). Buatois et al. (1998b) recognized three valid ichnospecies within Gordia: Gordia arcuata, Gordia marina and Gordia nodosa. Buatois et al. also transferred a fourth ichnospecies, Haplotichnus indianaensis, to Gordia, but we reject that reassignment because Haplotichnus indianensis exhibits projections at its joints and thus is a subjective junior synonym of Treptichnus bifurcus (Getty and Bush in press). Following comments by Pickerill and Peel (1991), Uchman et al. (2009) considered the differences between Mermia and Gordia insignificant and synonymized the two ichnogenera. These authors, however, chose to retain the ichnospecies Mermia carickensis (as Gordia carickensis) because it supposedly exhibited tighter looping than Gordia marina (Smith 1909, fig. 43; Walker 1985, fig. 8a). Thus, there are now four valid ichnospecies within Gordia. The specimens described herein are referred to Gordia carickensis because of their tight looping.

Ethologically, Gordia is classified as a grazing (pascichnia) or locomotion (repichnia) trace (Buatois et al. 1998b; Uchman et al. 2009). In nonmarine settings it is often attributed to small arthropods, nematodes, or other vermiform animals (Walker 1985; Metz 1987; Pickerill and Peel 1991; Buatois et al. 1998b; Minter et al. 2007a).
Ichnogenus Helminthoidichites Fitch 1850

Helminthoidichites tenuis Fitch 1850

(Fig. 6b)

1850 Helminthoidichites tenuis Fitch, p. 868, unnumbered fig.

MATERIAL: Numerous specimens on three slabs, SSM 2015/3-23, SSM 2015/3-24, and SSM 2015/3-26.

DESCRIPTION: Uniformly thin (0.1-0.3 mm wide), unornamented, bedding plane-parallel, straight to broadly curving (but not looping and crossing) trails that are preserved as concave epireliefs or convex hyporeliefs. Some trails exhibit a slight and irregular sinuosity along their length.

OCCURRENCE: The context of the specimens preserved on SSM 2015/3-23 and SSM 2015/3-24 was described above under Gordia carickensis. An additional slab, SSM 2015/326 , is similar to SSM 2015/3-23 in being shaly and preserving raindrop imprints, but the raindrop imprints are much larger on SSM 2015/3-26, having a diameter up to $10 \mathrm{~mm}$.

REMARKS: The ichnogenus Helminthoidichnites is similar in some respects to Gordia and Helminthopsis, but these latter two taxa are more sinuous than Helminthoidichnites. Gordia, for example, exhibits self-crossing and looping, and Helminthopsis characteristically meanders (e.g., Pickerill and Peel 1991; Han and Pickerill 1995; Buatois et al. 1998b; cf. Uchman et al. 2009).

With the exception of the specimen preserved on SSM 2015/3-26, these trails are found on slabs in association with Gordia carickensis. Furthermore, these specimens are approximately the same width as Gordia carickensis and exhibit the same low amplitude sinuosity along their lengths.
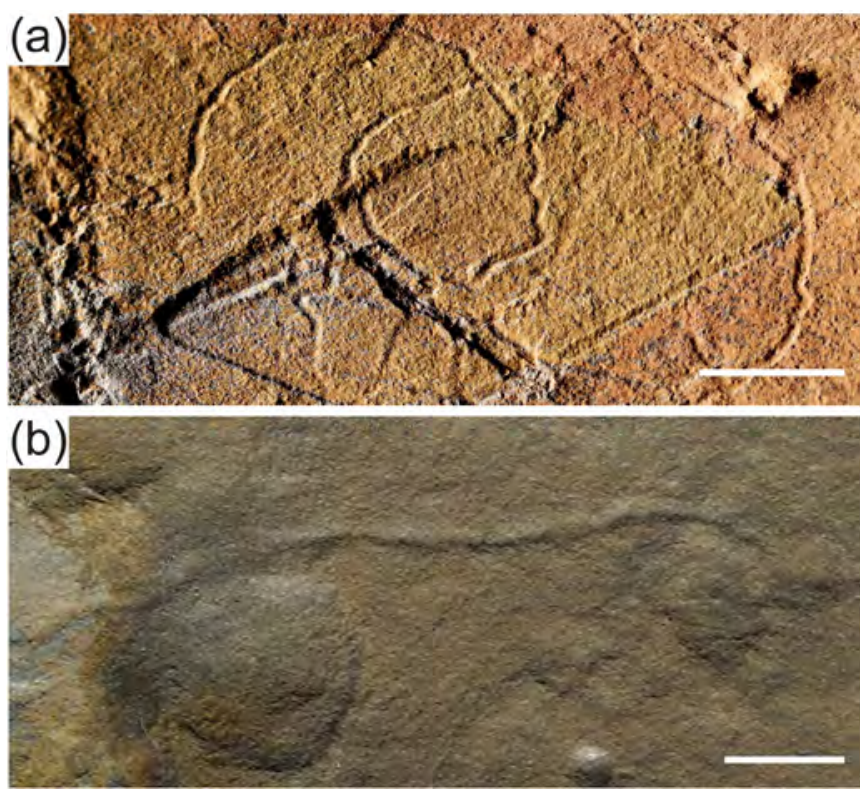

Figure 6. Gordia carickensis (a) on SSM 2015/3-23 and (b) Helminthoidichnites tenuis on SSM 2015/3-26. Scale bars are $5 \mathrm{~mm}$. 
The similarities between these two taxa, along with their cooccurrence, suggest that the same animal exhibiting different behaviors may have made them. This hypothesis about a common maker is further supported by observations made by MacNaughton and Pickerill (1995), who noted intergradations between Gordia marina and the straight to sinuous burrow Planolites isp.

Helminthoidichnites tenuis is classified as a grazing (pascichnia) or locomotion (repichnia) trace (Buatois et al. 1998b; Uchman et al. 2009). It is often attributed to small arthropods, nematodes, or other vermiform animals in nonmarine settings (Metz 1987; Buatois et al. 1998b; Uchman et al. 2009).

Ichnogenus Lockeia James 1879

Lockeia isp.

(Fig. 7)

MATERIAL: Multiple specimens preserved on part and counterpart slabs labeled SSM 2015/3-27 and SSM 2015/3-28.

DESCRIPTION: Ovoid, diamond-, or almond-shaped imprints preserved as convex hyporeliefs. The imprints have a maximum length of $3.0 \mathrm{~mm}$ and a maximum width of $2.3 \mathrm{~mm}$. The length to width ratio ranges from 1.3 to 2.4 . The traces are bisected by either a ridge or furrow running through their long axis.

OCCURRENCE: The slab on which these traces are preserved is composed of grey mudstone and exhibits ripple bedforms on its top (i.e., in epirelief).

REMARKS: James (1879) established Lockeia siliquaria for Silurian traces from Ohio that he thought were fossilized plants. Later, Seilacher (1953) erected Pelecypodichnus amygdaloides for similar traces that he attributed to the burrowing of bivalves. This latter ichnogenus, however, is commonly regarded as a junior synonym of Lockeia (Maples and West 1989; Seilacher and Seilacher 1994). Rindsberg (1994), Seilacher and Seilacher (1994), and Schlirf et al. (2001) erected new ichnospecies of Lockeia for bivalve traces with slightly different morphologies.

The Massachusetts specimens of Lockeia are smaller than those specimens commonly attributed to bivalves, so bivalves are not considered likely makers for the fossils described here. By contrast, burrowing bivalved arthropods, such as conchostrachans and ostracodes, produce traces similar to the Massachusetts specimens (Tasch 1964; Voigt and Hartmann 1970). Other researchers (e.g., Pollard and Hardy 1991; Buatois et al. 2000; Minter and Braddy 2009) described small Lockeia that they attributed to such arthropods, but no ichnospecies has been established for these traces.

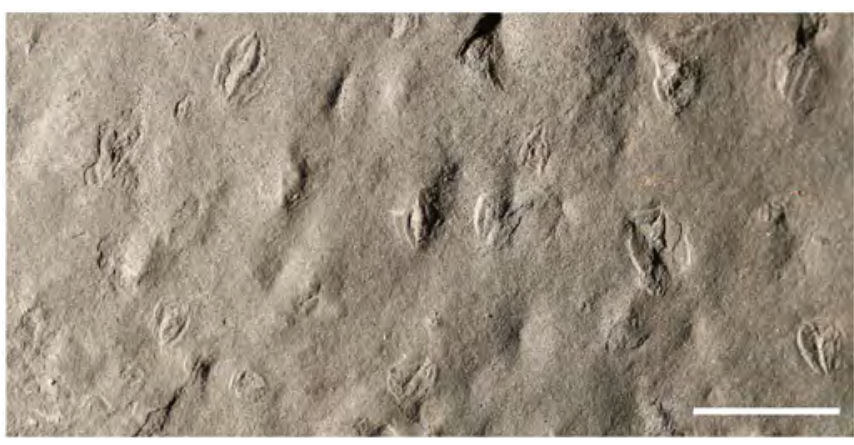

Figure 7. Numerous Lockeia isp. preserved on SSM 2015/327. Scale bar is $5 \mathrm{~mm}$.

\section{Ichnogenus Mitchellichnus Walker 1985}

Mitchellichnus cf. ferrydenensis Walker 1985

(Fig. 8)

\section{cf. 1985 Mitchellichnus ferrydenensis Walker, p. 293,} fig. 7.

MATERIAL: One specimen, YPM IP 227941

DESCRIPTION: A trackway preserved in convex hyporelief that is composed of two lateral track rows and three medial impressions. The external width of the trackway is $6.4 \mathrm{~mm}$ and the internal width is $3.0 \mathrm{~mm}$. Within the track rows, the tracks are grouped by threes into series that are triangular or linear in outline, the latter being oblique and staggered forward from $55^{\circ}$ to $88^{\circ}$ relative to the axis of the trackway. Series have a repeat distance (stride length) from 1.9 to $2.7 \mathrm{~mm}$ and exhibit staggered to opposite symmetry relative to the trackway axis. On the left side of the trackway, the tracks are circular to ovate in outline and measure up to $0.3 \mathrm{~mm}$ wide, but those on the right side of the trackway are elongate and parallel to the trackway axis, are dashto teardrop-shaped, and have a maximum length of 0.8 $\mathrm{mm}$. The medial impressions are closely spaced, measuring

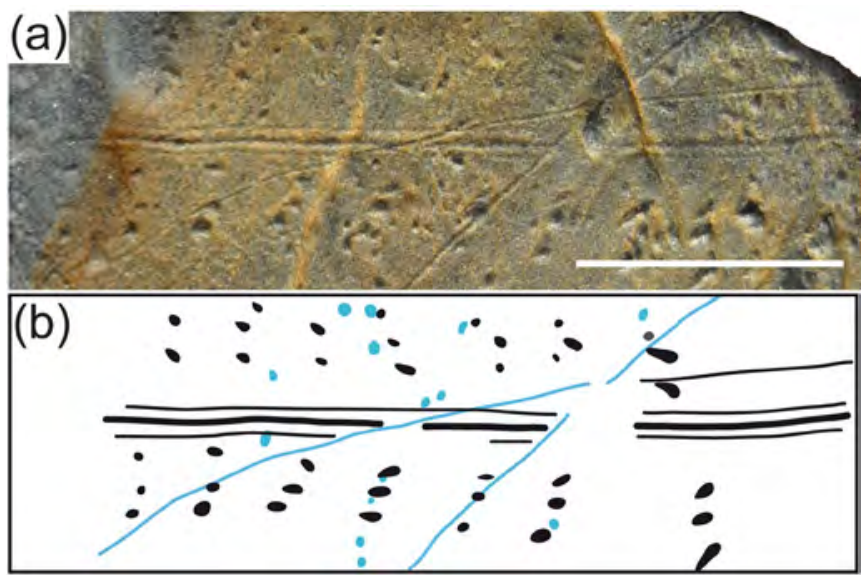

Figure 8. Photograph (a) and interpretive drawing (b) of YPM IP 227941, a Mitchellichnus cf. ferrydenensis (colored black) trackway crossed by YPM IP 227942 and 227943, which are Stiaria intermedia trackways (colored blue). Scale bar is $10 \mathrm{~mm}$. 
only 0.1 to $0.2 \mathrm{~mm}$ apart. The central medial impression is deeper and thicker, measuring approximately $0.3 \mathrm{~mm}$ wide, whereas the two lateral impressions are shallow and thin, measuring approximately $0.1 \mathrm{~mm}$ wide.

OCCURRENCE: This trackway occurs on a small slab of grey shale that exhibits mudcracks and raindrop imprints. Additional invertebrate trace fossils in direct association with Mitchellichnus cf. ferrydenensis include Siskemia elegans and Stiaria intermedia (Getty et al. 2013, figs. 3A-3B).

REMARKS: Walker (1985) established the monospecific ichnogenus Mitchellichnus for Devonian arthropod trackways consisting of three separate elements: three medial drags, oblique series of six small imprints on both sides of the drags, and two outer series of tracks composed of three imprints. Walker (1985) noted, however, that the trackway often lacked the oblique series of six imprints. She attributed this trackway to swimming arthropods, tentatively proposing a eurypterid track maker.

The trackways from Massachusetts is similar to Devonian Mitchellichnus trackways that lack the oblique series of six imprints, but are smaller. Getty et al. (2013) showed that archaeognathan insects could produce small Mitchellichnus trackways when the animal dragged its terminal filament and lateral cerci/abdominal styli, thereby producing the characteristic triple medial drag.

Although size is generally not considered a valid ichnotaxobase (Bertling et al. 2006; Buatois and Mángano 2011), Minter and Braddy (2006a, p. 1135) argued that size differences of an order of magnitude can be validly used when no intermediate sized specimens are found. Considering that the Massachusetts trackways are an order of magnitude smaller than Devonian Mitchellichnus ferrydenensis, a case could be made for assigning the Massachusetts specimens to a new ichnospecies. Getty et al. (2013), however, were reluctant to establish a new ichnospecies because their experiments with archaeognathan insects yielded trackways with different numbers of medial drags along their lengths as a result of minor behavioral and substrate variations, and such minor variations are considered grounds for synonymizing taxa (Minter et al. 2007b). The identification of fossilized archaeognathan trackways with different numbers of medial drags along their lengths (e.g., Buatois et al. 1998b; Voigt et al. 2013) lends support to the cautious approach taken by Getty et al. (2013). For now, we attribute the Massachusetts material to Mitchellichnus, but do not assign it to a species.

\section{Narragansettichnus new ichnogenus.}

TYPE SPECIES: Narragansettichnus fortunatus, by monotypy.

HOLOTYPE: YPM IP 237253, housed in the Invertebrate Paleontology collections of the Yale Peabody Museum.

ETYMOLOGY: For the Narragansett Basin in which it was found, and ichnos, Greek for a footprint or trace.

OCCURRENCE: Carboniferous (Westphalian C) Rhode Island Formation of Massachusetts.
DIAGNOSIS: Bilaterally-symmetrical, bedding-plane-parallel trace divided longitudinally into three distinct regions. Anterior region consists of a small central depressed area from which short imprints project laterally. Middle region consists of three pairs of elongate imprints, arranged one in front of the other, that are thicker near the midline of the trace and taper distally. Posterior region elongate, segmented, and tapered only slightly.

REMARKS: This trace bears superficial resemblance to Tonganoxichnus, but the two ichnogenera differ in many respects, including the following: (1) Narragansettichnus lacks the elongate maxillary palp imprints present in Tonganoxichnus; (2) Narragansettichnus lacks the styli imprints characteristic of Tonganoxichnus; (3) Narragansettichnus has much longer paired imprints in its middle region than does Tonganoxichnus; (4) Narragansettichnus has an elongate posterior region that tapers only slightly, whereas the posterior region of Tonganoxichnus tapers considerably more; and (5) Narragansettichnus lacks the elongate filament imprint on the end of the posterior region of Tonganoxichnus.

This trace also bears significant resemblance to the unnamed ephemeropteran body imprint described by Knecht et al. (2011) from the Carboniferous Wamsutta Formation of Massachusetts. Indeed, a case can be made that the two traces are congeneric. If so, the Wamsutta Formation trace would likely constitute a new ichnospecies based on minor morphological differences between the two traces (see Appendix B). Considering that Knecht et al. (2011) interpreted the Wamsutta body imprint as that of a volant sub-adult or adult, the differences between the two imprints may be the result of ontogenic variability.

According to the ethological classification of Seilacher (1953), this imprint would be considered a cubichnion, or resting trace. We note, however, that animals producing "resting traces" may be engaged in a variety of behaviors (Martin 2006; Getty et al. 2013), and that it is difficult to say with certainty what the animal was doing. Considering the lithology of the slab on which the trace is preserved, the lack of subaerially produced sedimentary structures, and the probable gill imprints, we suggest that the body imprint was produced subaqueously.

\section{Narragansettichnus fortunatus new ichnospecies.}

$$
\text { (Fig. 9) }
$$

ETYMOLOGY: Latin, furtunatus, fortunate, for the luck in having found the fossil.

HOLOTYPE: YPM IP 237253, housed in the Invertebrate Paleontology collections of the Yale Peabody Museum.

OCCURRENCE: This trace occurs on a slab of dark grey, lightly metamorphosed shale. Fragmentary carbonized plant fossils occur on both the top and bottom of the slab, but no other trace fossils are present. Sedimentary structures include small (1.4-1.9 mm maximum diameter) ovate features that are here interpreted as gas-escape structures due 

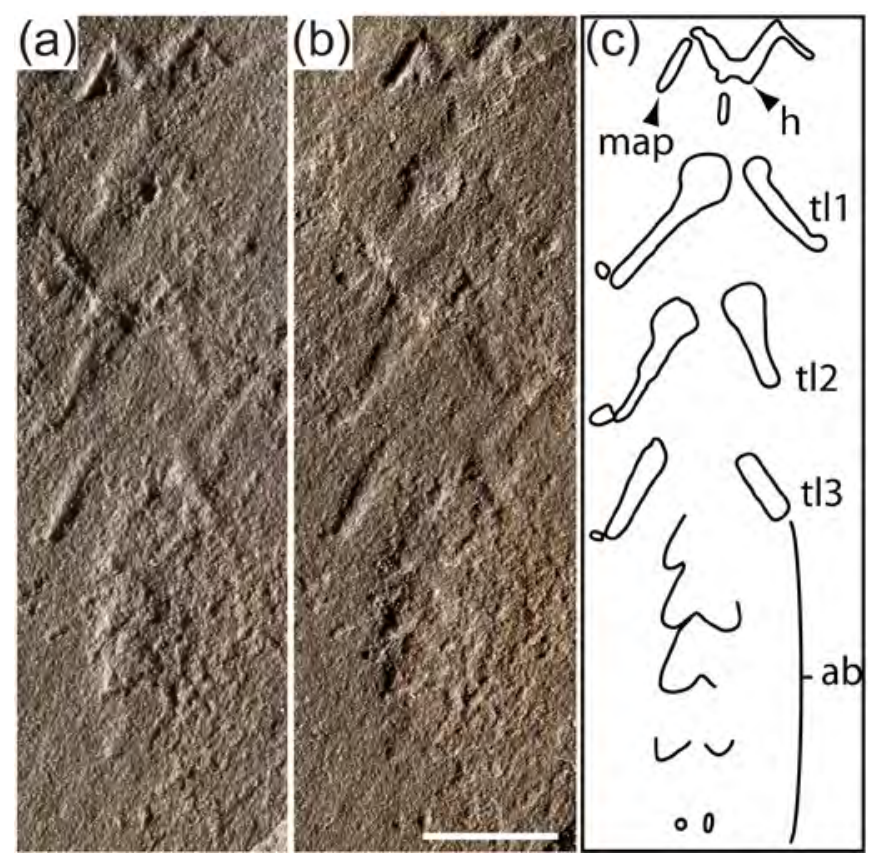

Figure 9. YPM IP 237253, Narragansettichnus fortunatus new ichnogenus and ichnospecies, the body imprint of an insect (probably ephemeropteran) from the Pennsylvanian Rhode Island Formation of Massachusetts, with an interpretive line drawing. (a) The specimen as illuminated from the upper left. (b) The specimen as illuminated from the lower right. (c) Interpretive line drawing. Abbreviations as in Figure 6, with the addition of the following: map, maxillary palp. Scale bar is $5 \mathrm{~mm}$.

to the dark, organic-rich sediment in which they formed, as well as the lack of other sedimentary structures (e.g., mudcracks) that indicate subaerial exposure (Rindsberg 2005).

DIAGNOSIS: As for the ichnogenus.

DESCRIPTION: This trace is preserved in convex hyporelief and measures $25.1 \mathrm{~mm}$ long by up to $6.8 \mathrm{~mm}$ wide. The anterior region of the trace is composed of two chevron-shaped imprints that are connected along the midline of the trace by a roughly triangular imprint, such that the whole structure resembles a capital letter $M$. The chevrons are formed by two "arms" offset at an angle of $72^{\circ}$ on the right side of the trace and $78^{\circ}$ on the left side. The inner arms of the chevrons are shorter $(1.1-1.4 \mathrm{~mm})$ than the outer arms (1.6-1.7 mm), but form the apex of the chevrons. There is a small gap in each chevron between the outer and inner arms. The outer arms of the chevrons are nearly uniformly thin (ca. $0.2 \mathrm{~mm}$ ) and are thinner than the inner arms of the chevrons $(0.6-0.7 \mathrm{~mm})$, which taper toward the chevron's apex. The central triangular structure is $1.4 \mathrm{~mm}$ wide and $0.8 \mathrm{~mm}$ long. A straight imprint, measuring $0.8 \mathrm{~mm}$ long, is located posterior to the triangular imprint; it is oriented parallel to, but offset to the right side of, the midline of the trace.

The central region of the trace consists of three pairs of elongate imprints arranged one in front of the other. Each elongate imprint, measuring from 1.8 to $5.3 \mathrm{~mm}$ long, is directly opposite its mate in the pair. Individual imprints are oriented posterolaterally at angles ranging from $140^{\circ}$ to $151^{\circ}$. All of the imprints taper distally, but the first two on the right side of the trace are extremely wide (1.3-1.8 $\mathrm{mm}$ ) and bulbous medially. The distal tips of some of the imprints are deflected slightly laterally and to the anterior.

The posterior region measures $9.2 \mathrm{~mm}$ long by a maximum of $2.3 \mathrm{~mm}$ wide. It is composed of four pairs of triangular imprints and a posterior pair of small (0.4-0.5 $\mathrm{mm}$ long) ovate imprints. Each imprint within a pair is directly opposite the other. The first three pairs of triangular imprints are relatively complete, but only the tips of the fourth pair are present. The triangular imprints have a long axis that is oriented posterolaterally at angles ranging from $20^{\circ}$ to $35^{\circ}$. The lateral margin of the posterior region has a sawtooth appearance as a result of the triangular imprints.

REMARKS: This trace is most likely that of an arthropod due to its division into discrete anterior, central, and posterior units, which are here interpreted as imprints of the head, thorax, and abdomen, respectively. We infer that the chevron-shaped units within the head imprint were made by mouthparts, possibly mandibular palps, and that the ventral surface of the head made the triangular imprint between the chevrons. The six elongate imprints within the thoracic region of the trace were most likely made by the thoracic legs, and their bulbous proximal portions may have been made by the coxae, whereas the femora probably made the long shafts of the leg imprints. The angled, distal tips of the leg imprints probably represent the joint between the femora and tibiae. The presence of six legs within the thoracic region suggests that the producer was most likely a hexapod, and due to its size, most likely an insect (see Appendix B).

The triangular imprints within the posterior region of the trace are here inferred to represent individual segments within the abdomen of the insect. Michael Engel of the University of Kansas (pers. comm., December 2009) suggested that these triangular structures may represent abdominal gills of an immature animal, and that the posterior orientation of the legs, the squat stance (with the head, thorax, and abdomen all touching the surface), the presumed abdominal gills, and the elongate shape of the trace are strongly suggestive of ephemeropterans. He pointed out, however, that plecopterans and other insects, such as palaeodictyopterans, cannot be ruled out due to the lack of terminal filament imprints. 
Ichnogenus Planolites Nicholson 1873

Planolites montanus Richter 1937

(Fig. 10)

1937 Planolites montanus Richter, p. 151, figs. 1-5.

MATERIAL: Numerous specimens on one slab, SSM 2015/3-29.

DESCRIPTION: Cylindrical burrows that are parallel, oblique, or nearly normal to bedding. Bedding-parallel burrows show gentle to sharp turns and may exhibit sinuous paths. Burrow diameters range from 0.9-4.9 mm. Burrows can be followed for a distance of up to $23 \mathrm{~mm}$. The fill appears to be the same under low power magnification, although the texture is different such that the burrows stand out when the slab is placed under low-angle light.

OCCURRENCE: These burrows occur within a slab of grey mudstone that also exhibits desiccation cracks. No other trace fossils occur on the slab with these burrows.

REMARKS: The ichnogenus Planolites is similar to Palaeophycus, but the two can be differentiated by the presence of a burrow wall lining in the latter and its absence in the former (Pemberton and Frey 1982; Keighley and Pickerill 1995). Pemberton and Frey (1982) also proposed to differentiate the two taxa based on the type of backfill relative to the host rock, but Keighley and Pickerill (1995) considered this and all other ichnotaxobases to be of lesser importance than the presence or absence of a wall lining in differentiating the two taxa.

Pemberton and Frey (1982) recognized three valid ichnospecies within Planolites: Planolites annularis, Planolites beverleyensis and Planolites montanus. The material described herein lacks the diagnostic annulations of Planolites annularis and is smaller and more tightly contorted than Planolites beverleyensis. Consequently, this material is assigned to Planolites montanus. Likely producers of Planolites in continental settings include a wide variety of wormlike animals (Pemberton and Frey 1982), as well as insect larvae (Buatois and Mángano 1993).

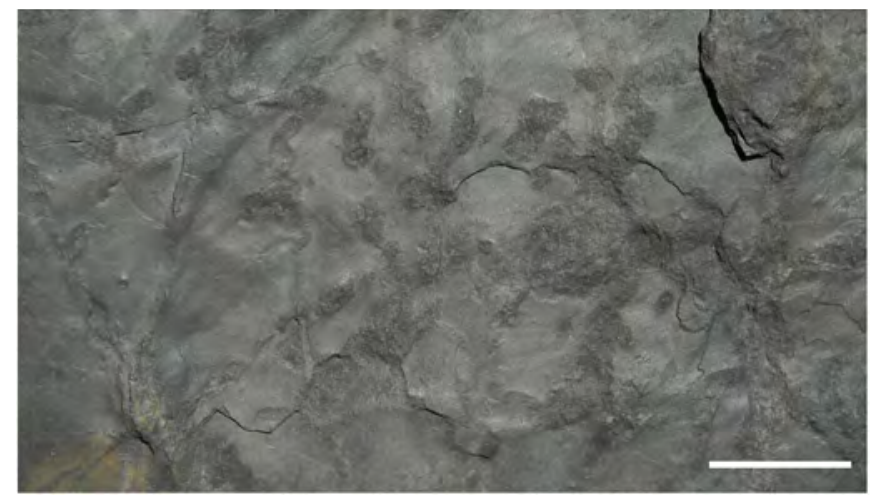

Figure 10. SSM 2015/3-29, a slab bearing Planolites montanus from the Pennsylvanian Rhode Island Formation of Massachusetts. Scale bar is $20 \mathrm{~mm}$.

\section{Ichnogenus Siskemia Smith 1909}

Siskemia elegans Smith 1909

(Figs. 11a-b)

1909 Siskemia elegans Smith, p. 5, frontispiece.

MATERIAL: One specimen, YPM IP 227939.

DESCRIPTION: A trackway, preserved in convex hyporelief, which is composed of two lateral track rows and two deep medial impressions. The external and internal widths of the trackway are, respectively, $7.4 \mathrm{~mm}$ and $2.8 \mathrm{~mm}$. Within the track rows, the tracks are grouped by threes into linear series that are oblique to the trackway axis at angles from $52^{\circ}$ to $97^{\circ}$. Series have a stride from 2.6 to 3.6 $\mathrm{mm}$ and exhibit staggered to alternate symmetry relative to the trackway axis. The individual tracks are elongate and crescent- to teardrop-shaped in outline and have a maximum length of $2.6 \mathrm{~mm}$. In many instances the tracks join proximally to form a single, trifid impression. The medial impressions are $0.4 \mathrm{~mm}$ apart and are about $0.3 \mathrm{~mm}$ wide. They are continuous and are of about equal depth.

OCCURRENCE: This trackway occurs on a small grey shale slab exhibiting mudcracks and raindrop imprints (Getty et al. 2013, figs. 3A-B). Co-occurring invertebrate traces include Mitchellichnus cf. ferrydenensis and Stiaria intermedia.

DISCUSSION: The ichnogenus Siskemia was established by Smith (1909) for arthropod trackways with two medial imprints. At the time it was established, eight species were recognized. In her revision of Smith's work, Walker (1985) reduced the number of included ichnospecies to three, including Siskemia elegans, Siskemia bipediculus, and Siskemia lata-via. Siskemia bipediculus has widely separated series of two to three tracks, whereas Siskemia lata-via has closely spaced series of three tracks. Siskemia elegans is smaller than the other two species and consists of two medial imprints between two rows of tracks arranged into discrete series of up to four tracks. The Massachusetts material is more similar to the Siskemia elegans in size and morphology, and is thus assigned to that species.

Walker (1985) proposed that Siskemia elegans was produced by a swimming crustacean. Buatois et al. (1998b) described Siskemia elegans-like trackways from the Carboniferous of Kansas, which they attributed to the locomotion of archaeognathan insects. Getty et al. (2013) showed that modern archaeognathan insects produce Siskemia eleganslike trackways when their abdominal styli drag in the mud, producing the characteristic double medial impressions. Considering that experimental results demonstrated that archaeognathan insects can produce such traces, and the occurrence of the archaeognathan body impression Tonganoxichnus in the same quarry, Getty et al. (2013) attributed the Massachusetts examples to archaeognathans. 

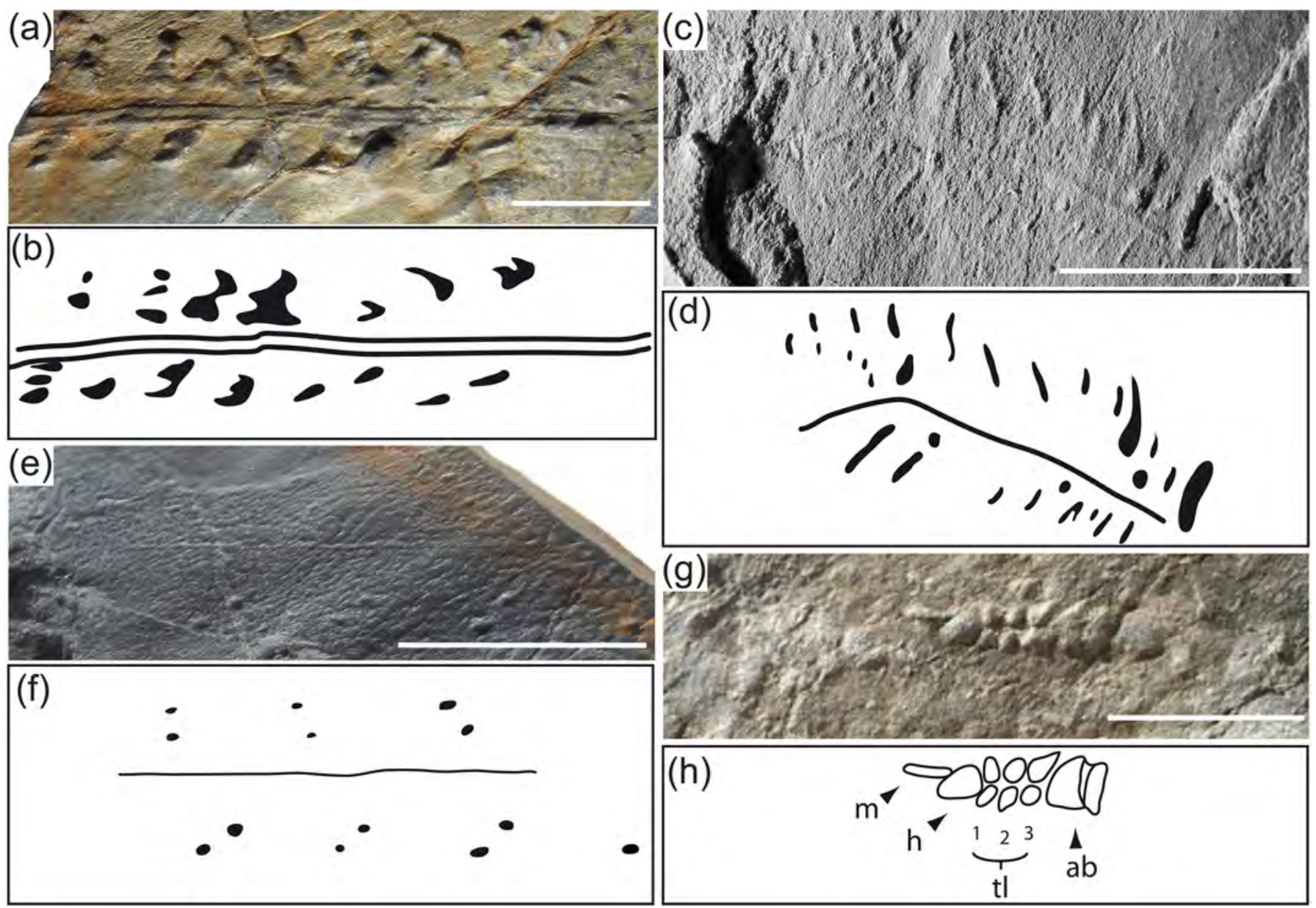

Figure 11. Various archaeognathan insect trace fossils from the Pennsylvanian Rhode Island Formation of Massachusetts. The direction of locomotion was from right to left in all examples. Photograph (a) and interpretive drawing (b) of YPM IP 227939, a Siskemia elegans trackway. Photograph (c) and interpretive drawing (d) of YPM IP 236965, a Stiallia pilosa trackway. Photograph (e) and interpretive drawing (f) of YPM 227946, a Stiaria intermedia trackway. Photograph (g) and interpretive drawing (h) of SSM 2007/06-40, a Tonganoxichnus buildexensis body imprint. Abbreviations: ab, abdomen; h, head; m, maxillary palp; tl 1-3, thoracic legs one through three. All scale bars are $10 \mathrm{~mm}$.

\section{Ichnogenus Stiallia Smith 1909}

Stiallia pilosa Smith 1909

(Figs. 11c-d)

1909 Stiallia pilosa Smith, p. 15, fig. 23.

MATERIAL: Two specimens, YPM IP 236965 and YPM IP 237004.

DESCRIPTION: YPM IP 236965 is a trackway preserved in convex hyporelief that is composed of two lateral rows of elongate tracks and a single medial impression. The external width of the trackway is $7.4 \mathrm{~mm}$ and the internal width is variable, ranging from 1.5 to $3.2 \mathrm{~mm}$. The tracks are oriented obliquely to the long axis of the trace, at angles ranging from $56^{\circ}$ to $90^{\circ}$, and the stride between them is 0.4 to $2.1 \mathrm{~mm}$. Individual tracks are elongate and ovate, teardropshaped, or wavy in outline. The medial impression is 0.5 $\mathrm{mm}$ wide and is continuous.
YPM IP 237004 (see Getty et al. 2013, figs. 3I-J) is a 7.9-mm-wide trackway preserved in convex hyporelief. It is composed of three separate elements: a single row of overlapping tracks on the right (as preserved) side of the trace; a single medial impression; and short, thin arcuate impressions running parallel to the medial impression. The tracks are 0.7 to $3.1 \mathrm{~mm}$ long and have a maximum width of $0.4 \mathrm{~mm}$. They are oriented obliquely to nearly parallel to the long axis of the trace, and are sometimes arranged into groups of two to three. Individual tracks are straight and dash-shaped, or slightly pinched and teardrop-shaped in outline. The medial impression is discontinuous and measures from 0.2 to $0.4 \mathrm{~mm}$ wide. The shorter impressions are $0.1 \mathrm{~mm}$ wide.

OCCURRENCE: The two specimens occur on blocky, grey mudstone slabs. YPM IP 237004 co-occurs with the small temnospondyl trackway Batrachichnus.

REMARKS: Smith (1909) established the ichnogenus Stiallia, with five included ichnospecies, for traces consist- 
ing of thin, elongate scratch marks that he observed in the Devonian Old Red Sandstone of Scotland. Walker (1985) re-examined Smith's material and synonymized all other Stiallia species with Stiallia pilosa. Walker (1985) also considered Carrickia to be a subjective junior synonym of Stiallia, but retained its one included species as Stiallia berriana. Thus, Stiallia has two ichnospecies, Stiallia pilosa and Stiallia berriana. The latter ichnospecies can be differentiated from Stiallia pilosa in that it has chevron-shaped medial imprints (Smith 1909, fig. 28; Walker 1985, fig. 9b). The material described herein lacks chevron-shaped medial imprints and bears a stronger resemblance to Stiallia pilosa in having two rows of elongate grooves between which is a long, thin medial drag mark. We thus assign the material to Stiallia pilosa.

In addition to the Devonian examples described by Smith (1909) and Walker (1985), Buatois et al. (1998b) identified Stiallia pilosa in the Carboniferous Tonganoxie sandstone of eastern Kansas. Whereas Smith (1909) did not offer a trace maker and Walker (1985) suggested only an arthropod producer, Buatois et al (1998b) tentatively attributed the Carboniferous examples to apterygote insects due to their close association with the body imprint Tonganoxichnus ottawensis. Similarly, we attribute the Massachusetts Stiallia pilosa to apterygote insects, specifically archaeognathans, due to the occurrence of Tonganoxichnus buildexensis at the same locality (Getty et al. 2013).

Both Smith (1909) and Walker (1985) considered Stiallia to be a swimming trace. By contrast, Buatois et al. (1998b) suggested that the Carboniferous examples were most likely the result of a combination of locomotion and feeding of apterygotes. Experiments with modern archaeognathans, however, show that Stiallia-like traces occurred when the insects' terminal filament became stuck in the mud and the animals clawed at the substrate in an attempt to free themselves (Getty et al. 2013, figs. 6F-G). We favor the hypothesis that the Carboniferous Stiallia pilosa from Kansas and Massachusetts resulted from entrapment in the mud because these fossils exhibit prominent medial drag marks, which indicate that the animals dragged their terminal filaments.

\section{Ichnogenus Stiaria Smith 1909}

Stiaria intermedia Smith 1909

(Figs. 8a-b, 11e-f)

1909

Stiaria intermedia Smith, p. 11, fig. 16.

MATERIAL: Seven specimens, YPM IP 227940, YPM IP 227942-46, and YPM IP 236963.

DESCRIPTION: Trackways preserved in concave epirelief or convex hyporelief that are composed of two lateral track rows and may have a medial impression. The external width of the trackways range from 5.1 to $7.1 \mathrm{~mm}$, and internal widths range from $2.1 \mathrm{~mm}$ and $3.7 \mathrm{~mm}$. Within the track rows, the tracks are grouped by threes into triangular or linear series, the latter of which are oblique to and oriented forward relative to the trackway axis at angles from $32^{\circ}$ to $86^{\circ}$. The series exhibit staggered to opposite symmetry relative to the trackway axis and have a stride length from 1.9 to $5.2 \mathrm{~mm}$. The individual tracks occur as small circular depressions with diameters of 0.3 to $0.8 \mathrm{~mm}$, or as straight, crescentic, or teardrop-shaped depressions with a maximum length of $1.9 \mathrm{~mm}$. When present, the medial impression is usually of uniform thickness ( 0.1 to $0.2 \mathrm{~mm}$ ), but one example pinches and swells along its length. One trackway, YPM IP 227944, has a very short segment with a double medial impression.

OCCURRENCE: These trackways occur on two small grey shale slabs (Getty et al. 2013, figs. 3A-3D). Sedimentary structures associated with these trackways include mudcracks and raindrop imprints. Associated invertebrate trace fossils include the insect trackways Mitchellichnus cf. ferrydenensis and Siskemia elegans, and vertebrates are represented by a partial, indeterminate tetrapod track.

REMARKS: Like Siskemia and Stiallia, Stiaria was established by Smith (1909) and was revised by Walker (1985). The latter author considered a single medial impression to be an important defining characteristic of Stiaria and moved the species Danstaria intermedia to Stiaria due to the presence of that feature. Walker (1985) also noted that Stiaria was similar to Paleohelcura, but that Stiaria could have more tracks per set and more variety in the arrangements of tracks within the set than Paleohelcura. Other researchers (e.g., Buatois et al. 1998b; Minter and Braddy 2009) also noted the similarity between Stiaria and Paleohelcura, and in particular, Stiaria intermedia and Paleohelcura tridactyla. Buatois et al. (1998b) agreed with Walker's (1985) criteria for differentiating the two taxa and offered an additional one: that Stiaria exhibits opposite symmetry whereas Paleohelcura exhibits alternate symmetry. Getty et al (2013), however, showed that archaeognathan insects can change gaits while walking and thus produce trackways with different types of symmetry along their length. Minter and Braddy (2009) pointed to observations by Brady (1947) that Paleohelcura tridacyla occasionally has four tracks per series, which is different from the maximum of three observed in Stiaria intermedia. These authors also argued that populations of Stiaria intermedia and Paleohelcura tridactyla have a statistically significant size difference and referred trackways less than $20 \mathrm{~mm}$ wide to Stiaria intermedia and those wider than $20 \mathrm{~mm}$ to Paleohelcura tridactyla. The Massachusetts specimens all have a maximum of three tracks per set and are less than $20 \mathrm{~mm}$ wide, and are therefore assigned to Stiaria intermedia.

Carboniferous and Permian Stiaria intermedia, including those described here, are often attributed to archaeognathan insects due to their co-occurrence, and occasional direct association, with the archaeognathan body imprint Tonganoxichnus (Buatois et al. 1998b; Lucas et al. 2005a, b; Minter and Braddy 2006b; Minter and Braddy 2009; Buta 
et al. 2013; Getty et al. 2013). Getty et al. (2013) also noted that specimens of Stiaria intermedia exhibiting opposite symmetry can be confidently attributed to archaeognathans because, among hexapods, only that group is capable of oppositely symmetric locomotion (Manton 1977).

Ichnogenus Tonganoxichnus Mángano et al. 1997

Tonganoxichnus buildexensis Mángano et al. 1997 (Figs. 11g-h)

1997 Tonganoxichnus buildexensis Mángano et al. p. 115 , fig. 3 .

MATERIAL: Thirteen specimens; SSM 2007/6-40, SSM 2011/9-1, SSM 2012/4-1, SSM 2012/4-2, SSM 2012/4-3, YPM IP 227991-227992, and YPM IP 236967-236972.

DESCRIPTION: Bilaterally symmetric traces preserved in concave epirelief and convex hyporelief that are divided longitudinally into anterior, central and posterior regions. The maximum length of these traces is $16.2 \mathrm{~mm}$. There is significant variability in the size of these traces due to a variety of factors, including differences in body size of the trace makers and differences in behavior/posture that resulted in different parts of the body touching the substrate.

The anterior region of the trace is composed of up to two components. One or two furrows, measuring up to $2.6 \mathrm{~mm}$ long, may occur at the front of this region, where they occur on opposite sides of, and are parallel to, the long axis of the trace. An ovate, rectangular, or irregularly shaped depression measuring 1.1 to $2.4 \mathrm{~mm}$ long lies behind the furrows and is positioned at the center of the longitudinal axis.

The central region of the trace consists of up to two elements as well. Medially, there are a maximum of three pairs of circular, ovate, or irregularly shaped depressions, each of which may be subdivided into two sections by a thin ridge of sediment. The pairs of depressions are arranged one behind the other to form two rows on opposite sides of, and parallel to, the long axis of the trace. The anterior pair of depressions is oriented anteriorly to anterolaterally, at $23^{\circ}$ to $83^{\circ}$ relative to the midline of the trace, whereas the central pair of depressions is oriented anterolaterally to laterally $\left(57^{\circ}\right.$ and $120^{\circ}$ ), and the posterior pair is oriented laterally to posterolaterally $\left(92^{\circ}\right.$ to $\left.157^{\circ}\right)$. In addition, some specimens have ovate to teardrop-shaped depressions lateral to the paired medial impressions, measuring from 0.4 to $0.5 \mathrm{~mm}$ long. In one specimen (SSM 2011/6-40) a shallow furrow connects a medial and a lateral depression.

The posterior region is composed of a rectangular to ovate depression that is often subdivided into discrete subsections by thin ridges of sediment oriented perpendicular to the long axis of the trace. The subsections of this region have an overall length of 0.7 to $1.7 \mathrm{~mm}$. Each subsection typically exhibits a pair of furrows, one on either side of the trace. The furrows are arranged into chevrons that open toward the rear and have apical angles ranging from $21^{\circ}$ to $52^{\circ}$.
OCCURRENCE: Tonganoxichnus occurs on slabs of grey mudstone and shale that often, but not always, have raindrop imprints and mud cracks. Some specimens have been found alongside fossilized plants. Associated temnospondyl trace fossils include the trackways Batrachichnus, which represents walking behavior, and Characichnos isp., which represents swimming behavior. Associated arthropod trackways include Diplichnites.

REMARKS: Mángano et al. (1997) established Tonganoxichnus for invertebrate body imprints from the Upper Carboniferous Tonganoxie sandstone of Kansas; they included two ichnospecies, Tonganoxichnus buildexensis and Tonganoxichnus ottawensis, within the genus. The two ichnospecies were differentiated in that the former has paired imprints in the inferred anterior region of the trace, whereas the latter has multiple bifid scratch marks in the same region. Later, Braddy and Briggs (2002) established Tonganoxichnus robledoensis for multiple imprints in a row, and Hedriumichnus apacheensis (now Tonganoxichnus apacheensis, see Minter and Braddy 2009) for traces with v-shaped leg imprints. Benner et al. (2015) erected a new ichnospecies, Tonganoxichnus attleboroensis, and moved Tonganoxichnus ottawensis to their new ichnogenus Cardinichnus. The Massachusetts specimens most closely resemble Tonganoxichnus buildexensis in their morphology and are therefore assigned to that ichnospecies.

Mángano et al. (1997) argued that Tonganoxichnus was most likely produced by monuran insects because the detailed anatomy of the traces matched that of known monurans. Subsequent authors (e.g., Mángano et al. 2001; Braddy and Briggs 2002; Minter and Braddy 2006b) agreed with the attribution of Tonganoxichnus to monurans. Further, Sturm (1955) and Getty et al. (2013) showed that modern archaeognathans (Order Archaeognatha), the group to which the monurans belong (Grimaldi and Engel 2005), produce traces nearly identical to Tonganoxichnus under experimental conditions. Getty et al. (2013), however, showed that the behavioral inferences derived from Tonganoxichnus might be incorrect, at least in some cases. For example, Mángano et al. (1997) argued that Tonganoxichnus buildexensis and Tonganoxichnus ottawensis represented resting and feeding behavior, respectively. By contrast, in the experiments conducted by Getty et al. (2013), archaeognathans produced slightly different traces resembling Tonganoxichnus buildexensis based on whether the animal was jumping or landing. Further, traces similar to Tonganoxichnus ottawensis were produced by animals that had become stuck in the mud. Based on the experimental results of Getty et al. (2013), we argue that the Massachusetts Tonganoxichnus buildexensis that have terminal filament imprints were produced by archaeognathans during jumping, whereas those lacking the terminal filament imprint were most likely produced during landing. A probable landing trace is illustrated in Fig. 11g. 


\section{DISCUSSION}

Trace fossils examined are preserved on slabs with either one of two lithologies. The first lithology consists of laminated, light- to dark-grey siltstone on which sedimentary structures indicative of subaerial exposure, such as raindrop imprints and desiccation cracks, are absent. Some slabs with this lithology exhibit a distinct pinstripe pattern of laminae. This suite of sedimentary structures is consistent with deposition in a permanently subaqueous environment (Nichols 1999). Trace fossils from this environment include Cochlichnus anguineus, Diplichnites gouldi, and Narragansettichnus fortunatus, as well as the fish trail Undichna unisulca. This assemblage is consistent with the Mermia ichnofacies, which is found in permanently subaqueous lacustrine environments and is typically dominated by grazing trails (Buatois and Mángano 2011), but can be dominated by arthropod trackways (e.g., Aceñolaza and Buatois 1993), as are our specimens.

The second lithology consists of fine-grained, muddy sandstone or light-grey shale/mudstone. Sedimentary structures associated with this lithology include oscillation ripple marks, raindrop imprints, gas-escape structures and desiccation cracks, suggesting deposition under shallow subaqueous conditions with periodic drying of the sediment. This is consistent with the sediments being deposited in a variety of marginal lacustrine environments, although more specific determination of paleoenvironments is not possible since the slabs were not collected in situ. Trace fossils found in this paleoenvironment include Diplichnites cuithensis, Diplopodichnus biformis, Gordia carickensis, Helminthoidichites tenuis, Lockeia isp., Mitchellichnus cf. ferrydenensis, Planolites montanus, Siskemia elegans, Stiallia pilosa, Stiaria intermedia and Tonganoxichnus buildexensis. The traces from this sedimentary environment are consistent with the Scoyenia ichnofacies, which is found in lake-margin settings (Buatois and Mángano 2007, 2011).

\section{CONCLUSIONS}

Fourteen ichnotaxa, including Cochlichnus anguineus, Diplichnites cuithensis, Diplichnites gouldi, Diplopodichnus biformis, Gordia carickensis, Helminthoidichites tenuis, Lockeia isp., Mitchellichnus cf. ferrydenensis, Planolites montanus, Siskemia elegans, Stiallia pilosa, Stiaria intermedia, Tonganoxichnus buildexensis and Narragansettichnus fortunatus, a new ichnogenus and ichnospecies, have been recovered from a large, open-pit quarry in Massachusetts. The Carboniferous rocks on which the traces were produced represent lake-margin and lacustrine sedimentary facies, based on the sedimentology of the slabs on which the fossils were produced. Traces attributed to apterygote insects, arthropleurid myriapods, bivalved arthropods and vermiform animals occur in lake-margin sediments in association with those of temnospondyl amphibians and early diapsid reptiles, and belong to the Scoyenia ichnofa- cies. Lacustrine rocks have yielded a low-diversity Mermia ichnofacies consisting of trackways produced by aquatic arthropods, trails made by fish, and a body imprint possibly produced by an aquatic mayfly larva. If the maker of the body imprint has been correctly identified, then the trace represents one of the first records of ephemeropterans.

\section{ACKNOWLEDGMENTS}

We are indebted to the owners of the quarry for permission to collect the fossils described in this paper. We also thank Jarmila Kukalova-Peck for offering comments and insights concerning archaeognathans and thysanurans. We thank Michael Engel, Conrad Labandiera, and Jan Peters for assisting in determining the probable maker of Narragansettichnus fortunatus. PRG acknowledges the efforts of Neil Clark, Mark Dean, and Susan Martin for sending molds of type specimens of Siskemia and Stiaria for comparison to the Plainville fossils. We thank Jean Crespi and Meredith Fichman for helpful discussions on the deformation of the rocks and fossils. Andrew Bush and Sebastian Voigt offered insights into the depositional environments represented by the rocks in the quarry. We acknowledge Susan Butts of the Peabody Museum, as well as Richard Sanderson and David Stier of the Springfield Science Museum, for accessioning the specimens. The final draft of this paper benefited substantially from reviews provided by Lynn Dafoe and Randy Miller, and from the editing of Rob Fensome.

\section{REFERENCES}

Aceñolaza, F.G. and Buatois, L.A. 1993. Nonmarine perigondwanic trace fossils from the late Paleozoic of Argentina. Ichnos, 2, pp. 183-201. https://doi. org/10.1080/10420949309380092

Anderson, A.M. 1976. Fish trails from the Early Permian of South Africa. Palaeontology, 19, p. 397-409.

Benner, J.S., Knecht, R.J., and Engel, M.S. 2013. Comment on Marden (2013). Reanalysis and experimental evidence indicate that the earliest trace fossil of a winged insect was a surface skimming neopteran. Evolution, 67, pp. 2142-2149. https://doi.org/10.1111/evo.12094

Benner, J.S., Knecht, R.J., and Engel, M.S. 2015. Tonganoxichnus: a revision of the ichnogenus with new material from Massachusetts. In Ichnology: papers from Ichnia III. Edited by D. McIllroy. Geological Association of Canada, Miscellaneous Publication, 9, pp. 31-43.

Bertling, M., Braddy, S.J., Bromley, R.G., Demathieu, G.R., Genise, J., Mikuláš, R., Nielsen, J.K., Nielsen, K.S.S., Rindsberg, A.K., Schlirfg, M., and Uchman, A. 2006. Names for trace fossils: a uniform approach. Lethaia, 39, pp. 265-286. https://doi. org/10.1080/00241160600787890 
Billings, E. 1862. New species of fossils from different parts of the Lower, Middle, and Upper Silurian rocks of Canada. In Paleozoic fossils, volume 1. Geological Survey of Canada, pp. 96-168.

Braddy, S.J. and Briggs, D.E.G. 2002. New Lower Permian nonmarine arthropod trace fossils from New Mexico and South Africa. Journal of Paleontology, 76, pp. 546557. https://doi.org/10.1017/S0022336000037367

Bradshaw, M. 1981. Paleoenvironmental interpretations and systematics of Devonian trace fossils from the Taylor Group (lower Beacon Supergroup), Antarctica. New Zealand Journal of Geology and Geophysics, 24, pp. 615-652. https://doi.org/10.1080/00288306.1981.1 0421537

Bradshaw, M. 2010. Devonian trace fossils of the Horlick Formation, Ohio Range, Antarctica: systematic description and paleoenvironmental interpretation. Ichnos, 17, pp. 58-114. -https://doi. org/10.1080/10420941003659329

Brady, L.F. 1947. Invertebrate tracks from the Coconino sandstone of northern Arizona. Journal of Paleontology, 21, v. $466-472$.

Briggs, D.E.G. and Almond. J.E. 1994. The arthropleurids from the Stephanian (Late Carboniferous) of Montceaules-Mines (Massif Central, France). In Quand le Massif central était sous l'équateur. Mémoires de la section des sciences 12. Edited by C. H. Poplin. Comité des Travaux Historiques et Scientifiques, Paris, pp. 127-135.

Briggs, D.E.G., Rolfe, W.D.I., and Brannan, J. 1979. A giant myriapod trail from the Namurian of Arran, Scotland. Palaeontology, 22, pp. 273-291.

Buatois, L.A. and Mángano, M.G. 1993. The paleoenvironmental and paleoecological significance of turbiditic lake ichnocoenoses from the Late Carboniferous of the of the Paganzo Basin, Argentina. Comptes Rendus XII International CongressCarboniferous-Permian, 2, pp. 409-420.

Buatois, L.A. and Mángano, M.G. 2007. Invertebrate ichnology of continental freshwater environments. In Trace fossils: concepts, problems, prospects. Edited by W. Miller, III. Elsevier, Boston, pp. 285-323. https:// doi.org/10.1016/B978-044452949-7/50143-1

Buatois, L.A. and Mángano, M.G. 2011. Ichnology: organism-substrate interactions in space and time. Cambridge University Press, Cambridge, 358 p. https:// doi.org/10.1017/CBO9780511975622

Buatois, L.A., Mángano, M.G., Maples, C.G., and Lanier, W.P. 1998a. Taxonomic reassessment of the ichnogenus Beaconichnus and additional examples from the Carboniferous of Kansas, U.S.A. Ichnos, 5, pp. 287-302.

Buatois, L.A., Mángano, M.G., Maples, C.G., and Lanier, W.P. 1998b. Ichnology of an Upper Carboniferous fluvio-estuarine paleovalley: the Tonganoxie sandstone, Buildex Quarry, eastern Kansas, USA. Journal of Paleontology, 72, pp. 152-180. https://doi.org/10.1017/ S0022336000024094
Buatois, L.A., Mángano, M.G., Fregenal-Martinez, M.A., and de Gilbert, J.M. 2000. Short-term colonization trace-fossil assemblages in a carbonate lacustrine Konservat-Lagerstätte (Las Hoyas fossil site, Lower Cretaceous, Cuenca, central Spain). Facies, 43, pp. 145-156. https://doi.org/10.1007/BF02536988

Buta, R.J., Pashin, J.C., Minter, N.J., and KopaskaMerkel, D.C. 2013. Ichnology and stratigraphy of the Crescent Valley Mine: evidence for a Carboniferous megatracksite in Walker County, Alabama. New Mexico Museum of Natural History and Science Bulletin, no. 60, pp. 42-56.

Cleal, C.J. 1994. Plant fossils of the British Coal Measures, Palaeontological Association Field Guides to Fossils, No. 6. The Palaeontological Association, London, $222 \mathrm{p}$.

Dallmeyer, R.D. $1982 .{ }^{40} \mathrm{Ar} /{ }^{39} \mathrm{Ar}$ ages from the Narragansett Basin and southern Rhode Island basement terrane: their bearing on the extent and timing of Alleghenian tectonothermal events in New England. Geological Society of America Bulletin, 93, pp. 1118-1130. https:// doi.org/10.1130/0016-7606(1982)93<1118:AAFTNB> 2.0.CO;2

Davis, R.B., Minter, N.J., and Braddy, S.J. 2007. The neoichnology of terrestrial arthropods. Palaeogeography, Palaeoclimatology, Palaeoecology, 255, pp. 284-307. https://doi.org/10.1016/j.palaeo.2007.07.013

Dawson, J.W. 1873. Impressions and footprints of aquatic animals and imitative markings on Carboniferous rocks. American Journal of Science and Arts, 105, pp. 16-24. https://doi.org/10.2475/ajs.s3-5.25.16

de Gilbert, J.M., Buatois, L.A., Fregenal-Martínez, M.A., Mángano, M.G., Ortega, F. Poyato-Ariza, F.J., and Wenz, S. 1999. The fish trace Undichna from the Cretaceous of Spain. Palaeontology, 42, pp. 409-427. https://doi.org/10.1111/1475-4983.00079

Demathieu, G., Gand, G., and Toutin-Morin, N. 1992. A new name for the ichnogenus Arthropodichnus. Geobios, 25, pp. 19-54. https://doi.org/10.1016/S00166995(09)90036-5

Eiseman, C., and Charney, N. 2010. Tracks and sign of insects and other invertebrates. Stackpole Books, Mechanicsburg, Pennsylvania. 582 p.

Emmons, E. 1844. The Taconic System: based on observations in New York, Massachusetts, Maine, Vermont, and Rhode Island. Caroll and Cook, Albany, 68 p.

Fichman, J.H., Crespi, J., Getty, P.R., and Bush, A.M. 2015, Retrodeformation of Carboniferous trace fossils from the Narragansett Basin, U.S.A., using raindrop imprints and bedding-cleavage intersection lineation as strain markers. Palaios, 30, pp. 574-588. https://doi. org/10.2110/palo.2014.092

Fitch, A. 1850. A historical, topographical, and agricultural survey of the County of Washington. Part 2-5. Transactions of the New York Agricultural Society, 9, pp. 753-944. 
Getty, P.R. and Bush, A.M., in press. On the ichnotaxonomic status of Haplotichnus indianensis Miller (1889). Ichnos. https://doi.org/10.1080/10420940.2016.12702 10

Getty, P.R., Sproule, R., and Bush, A.M. 2010. Vertebrate trace fossil assemblages from the Pennsylvanian-aged Rhode Island Formation of eastern Massachusetts. Geological Society of America Abstracts with Programs, Northeastern Section, 42, p. 105.

Getty, P.R., Sproule, R., Wagner, D., and Bush, A.M., 2013. Variation in wingless insect trace fossils: insights from neoichnology and the Pennsylvanian of Massachusetts. Palaios, 28, pp. 243-258. https://doi.org/10.2110/ palo.2012.p12-108r

Gevers, T.W. 1973. A new name for the ichnogenus Arthropodichnus. Journal of Paleontology, 47, pp. 1002.

Gevers, T.W., Frakes, L.A., Edwards, L.N., and Marzolf, J.E. 1971. Trace fossils in the Lower Beacon sediments (Devonian), Darwin Mountains, southern Victoria Land, Antarctica. Journal of Paleontology, 45, pp. 81-94.

Gilmore, C.W. 1926. Fossil footprints from the Grand Canyon. Smithsonian Miscellaneous Collections, 77, pp. 1-41.

Grimaldi, D. and Engel, M.S. 2005. Evolution of the insects. Cambridge University Press, Cambridge, 755 p.

Hall, J. 1847. Palaeontology of New York, Volume 1 containing descriptions of the organic remains of the Lower Division of the New York System (equivalent to the Lower Silurian rocks of Europe). C. van Benthuysen, State of New York, Albany, $338 \mathrm{p}$.

Han, Y. and Pickerill, R.K. 1995. Taxonomic review of the ichnogenus Helminthopsis Heer 1877 with a statistical analysis of selected ichnospecies. Ichnos, 4, 83-118. https://doi.org/10.1080/10420949509380118

Haubold, H. 1970. Versuch der Revision der AmphibienFährten des Karbon und Perm. Freiberger Forschungshefte C, 260, pp. 83-117.

Haubold, H. 1971. Ichnia amphibiorum et reptiliorum fossilium. In Encyclopedia of palaeoherpetology, v. 18. Edited by O. Kuhn. Gustav Fischer, Verlag, Stuttgart. pp. 1-124.

Heer, O. 1876-1877. Flora fossilis Helvetae. Die Vorweltliche flora der Schweiz. Wurster and Co., Zurich, 182 p.

Hitchcock, E. 1858. Ichnology of New England. A report on the sandstone of the Connecticut Valley, especially its fossil footmarks. William White, Boston. 220 p.

International Commission on Zoological Nomenclature. 2012. Amendment of Articles 8, 9, 10, 21, and 78 of the International Code of Zoological Nomenclature to expand and refine methods of publication. ZooKeys, 219, pp. 1-10. https://doi.org/10.3897/ zookeys.219.3944

James, U.P. 1879. Description of new species of fossils and remarks on some others, from the Lower and Upper Silurian rocks of Ohio. The Paleontologist, 3, pp. 17-24.
Keighley, D.G. and Pickerill, R.K. 1995. The ichnotaxa Paleophycus and Planolites: historical perspectives and recommendations. Ichnos, 3, pp. 301-309. https://doi. org/10.1080/10420949509386400

Keighley, D.G. and Pickerill, R.K. 1996. Small Cruziana, Rusophycus, and related ichnotaxa from eastern Canada: the nomenclatural debate and systematic ichnology. Ichnos, 4, pp. 261-285. https://doi. org/10.1080/10420949609380136

Knecht, R.J. and Benner, J.S. 2008. Early- to midPennsylvanian vertebrate fauna of an intermontane basin inferred from tracks and trackways of the Wamsutta Formation, southeastern New England. Geological Society of America Abstracts with Programs, 40, p. 370.

Knecht, R.J., Benner, J.S., Gardulski, A.F., and Dean, J.L. 2009. A new Late Carboniferous trace fossil assemblage from the Wamsutta Fm. of Massachusetts and its significance. Geological Society of America Abstracts with Programs, 40, p. 370.

Knecht, R.J., Engel, M.S., and Benner, J.S. 2011. Late Carboniferous paleoichnology reveals the oldest fullbody impression of a flying insect. Proceedings of the National Academy of Sciences, 108, pp. 6515-6519. https://doi.org/10.1073/pnas.1015948108

Knox, A.S. 1944. A Carboniferous flora from the Wamsutta formation of southeastern Massachusetts. American Journal of Science, 242, pp. 130-138. https://doi. org/10.2475/ajs.242.3.130

Ksiazkiewicz, M. 1977. Trace fossils in the flysch of the Polish Carpathians. Paleontologica Polonica, 36, pp. $1-200$.

Linck, O. 1943. Die Buntsandstein-Kleinfahrten von Nagold (Limulidichnulus nagoldensis n.g. n.s., Merostomichnites triassicus n. sp.). Neues Jahrbuch für Mineralogie, Geologie und Paläontologie, Monatshefte, Abteilung B, 1943, pp. 9-27.

Lucas, S.G. 2007. Tetrapod footprint biostratigraphy and biochronology. Ichnos, 14, pp. 5-38. https://doi. org/10.1080/10420940601006792

Lucas, S.G., Minter, N.J., Spielman, J.A., Hunt, A.P., and Braddy, S.J. 2005a. Early Permian ichnofossil assemblage from the Fra Cristobal Mountains, southern New Mexico. New Mexico Museum of Natural History and Science Bulletin, no. 6, pp. 140150.

Lucas, S.G., Minter, N.J., Spielman, J.A., Smith, J.A., and Braddy, S.J. 2005b. Early Permian ichnofossils from the northern Caballo Mountains, Sierra County, New Mexico. New Mexico Museum of Natural History and Science Bulletin, no. 6, pp. 151-162.

Lucas, S.G., Lerner, A.J., Milner, A.R.C., and Lockley, M.G. 2006. Lower Jurassic invertebrate ichnofossils from a clastic lake margin, Johnson Farm, southwestern Utah. New Mexico Museum of Natural History and Science Bulletin, 37, pp. 128-136. 
Lull, R.S. 1920. An Upper Carboniferous footprint from Attleboro, Massachusetts, American Journal of Science, 50, pp. 234-236. https://doi.org/10.2475/ajs. s4-50.297.234

Lynn, E.R. and Krol, M.A. 2006. Microstructural analysis of the Rhode Island Formation from the Somerset drill core, Narragansett Basin, MA: evidence for Alleghanian upper greenschist-facies metamorphism and deformation. Geological Society of America Abstracts with Programs, 38, p. 91.

Lyons, P.C. 1984. Carboniferous megafloral zonation of New England. 9th International Congress of Carboniferous Stratigraphy and Geology, Compte Rendu, 2, pp. 503514.

Lyons, P.C. and Chase, H.B. Jr. 1976. Coal stratigraphy and flora of the northwestern Narragansett Basin. In Guidebook for field trips to the Boston area and vicinity. Edited by B. Cameron. New England Intercollegiate Geologic Conference, 68th Annual Meeting, Boston, pp. 405-427.

Lyons, P.C. and Chase, H.B., Jr. 1981. Rank of coal beds of the Narragansett basin, Massachusetts and Rhode Island. International Journal of Coal Geology, 1, pp. 155-168. https://doi.org/10.1016/01665162(81)90009-4

Lyons, P.C. and Darrah, W.C. 1978. A late Middle Pennsylvanian flora of the Narragansett basin, Massachusetts. Geological Society of America Bulletin, 89, pp. 433-438. https://doi.org/10.1130/00167606(1978)89<433:ALMPFO>2.0.CO;2

MacNaughton, R.B. and Pickerill, R. K. 1995. Invertebrate ichnology of the nonmarine Lepreau Formation (Triassic), southern New Brunswick, eastern Canada. Journal of Paleontology, 69, pp. 160-171. https://doi. org/10.1017/S0022336000027001

Mángano, M.G., Buatois, L.A., Maples, C.G., and Lanier, W.P. 1997. Tonganoxichnus, a new insect trace from the Upper Carboniferous of eastern Kansas. Lethaia, 30, pp. 113-125. https://doi.org/10.1111/j.1502-3931.1997. tb00451.x

Mángano, M.G., Labandeira, C.C., Kvale, E.P., and Buatois, L.A. 2001. The insect trace fossil Tonganoxichnus from the Middle Pennsylvanian of Indiana: paleobiologic and paleoenvironmental implications. Ichnos, 8, pp. 165-175. https://doi.org/10.1080/10420940109380184

Manton, S.M. 1977. The Arthropoda: habits, functional morphology, and evolution. Clarendon Press, Oxford. $514 \mathrm{p}$.

Maples, C.G., and West, R.R. 1989. Lockeia, not Pelecypodichnus. Journal of Paleontology, 63, pp. 694696. https://doi.org/10.1017/S0022336000041330

Marden, J.H. 2013a. Reanalysis and experimental evidence indicate that the earliest trace fossil of a winged insect was a surface-skimming neopteran. Evolution, 67, pp. 274-280. https://doi.org/10.1111/j.15585646.2012.01743.x
Marden, J.H. 2013b. Reply to "Comment on Marden (2013) regarding the interpretation of the earliest grace fossil of a winged insect." Evolution, 67, pp. 2150-2153. https://doi.org/10.1111/evo.12093

Maria, A. and Hermes O.D. 2001. Volcanic rocks in the Narragansett Basin, southeastern New England: petrology and significance to early basin formation, American Journal of Science, 301, pp. 286-312. https:// doi.org/10.2475/ajs.301.3.286

Martin, A.J. 2006. Resting traces of Ocypode quadrata associated with hydration and respiration: Sapelo Island, Georgia, USA. Ichnos, 13, pp. 57-67. https:// doi.org/10.1080/10420940600739575

Matthew, G.F. 1910. Remarkable forms of the Little River Group. Royal Society of Canada, Proceedings and Transactions, Third Series, 3, pp. 115-125.

Metz, R. 1987. Insect traces from nonmarine ephemeral puddles. Boreas, 16, pp. 189-195. https://doi. org/10.1111/j.1502-3885.1987.tb00770.x

Metz, R. 1988. Nematode trails from the Late Triassic of Pennsylvania. Ichnos, 5, pp. 303-308. https://doi. org/10.1080/10420949809386428

Miller, S. A. 1889. North American geology and paleontology for the use of amateurs, students, and scientists. Western Methodist Book Concern, Cincinnati. 664 p.

Minter, N.J. and Braddy, S.J. 2006a. The fish and amphibian swimming traces Undichna and Lunichnium, with examples from the Lower Permian of New Mexico, USA. Palaeontology, 49, pp. 1123-1142. https://doi. org/10.1111/j.1475-4983.2006.00588.x

Minter, N.J. and Braddy, S.J. 2006b. Walking and jumping with Palaeozoic apterygote insects. Palaeontology, 49, pp. 827835. https://doi.org/10.1111/j.1475-4983.2006.00571.x

Minter, N.J. and Braddy, S.J. 2009. Ichnology of an Early Permian intertidal flat: the Robledo Mountains Formation of southern New Mexico, USA. Special Papers in Palaeontology, 82, pp. 1-107.

Minter, N.J., Krainer, K., Lucas, S.G., Braddy, S.J., and Hunt, A.P. 2007a. Palaeoecology of an Early Permian playa lake trace fossil assemblage from Castle Peak, Texas, USA. Palaeogeography, Palaeoclimatology, Palaeoecology, 246, pp. 390-423. https://doi. org/10.1016/j.palaeo.2006.10.009

Minter, N.J., Braddy, S.J., and Davis, R.B. 2007b. Between a rock and a hard place: arthropod trackways and ichnotaxonomy. Lethaia, 40, pp. 365-375. https://doi. org/10.1111/j.1502-3931.2007.00035.x

Morrissey, L.B., Braddy, S.J., Bennett, J.P., Marriott, S.B., and Tarrant, P.R. 2004. Fish trails from the Lower Old Red Sandstone of Tredomen Quarry, Powys, southeast Wales. Geological Journal, 39, pp. 337-358. https://doi. org/10.1002/gj.998

Mosher, S. 1983. Kinematic history of the Narragansett Basin, Massachusetts and Rhode Island: constraints on late Paleozoic plate reconstructions. Tectonics, 2, pp. 327-344. https://doi.org/10.1029/TC002i004p00327 
Murray, D.P., Skehan, J.W., and Raben, J. 2004. Tectonostratigraphic relationships and coalifaction trends in the Narragansett and Norfolk basins, New England. Journal of Geodynamics, 37, pp. 583-611. https://doi.org/10.1016/j.jog.2004.02.006

Mutch, T.A. 1968. Pennsylvanian non-marine sediments of the Narragansett Basin of Massachusetts and Rhode Island, Late Paleozoic and Mesozoic continental sedimentation, northeastern North America. Geological Society of America Special Paper, 106, pp. 177-209.

Nichols, G. 1999. Sedimentology and stratigraphy. Blackwell, Malden, USA. 355 p.

Nicholson, H.A. 1873. Contributions to the study of errant annelids of the older Paleozoic rocks. Proceedings of the Royal Society of London, 21, pp. 288-290. https:// doi.org/10.1098/rspl.1872.0061

Oleksyshyn, J., 1976, Fossil plants of Pennsylvanian age from northwestern Narragansett Basin. In Studies in New England geology (C. Wroe Wolfe Volume), Geological Society of America Memoir 146. Edited by P.C. Lyons and A. H. Brownlow. Geological Society of America, Boulder, pp. 143-179.

Packard, A.S. 1900a. View of the Carboniferous fauna of the Narragansett Basin. Proceedings of the American Academy of Arts and Sciences, 35, pp. 399-405. https:// doi.org/10.2307/25129951

Packard, A.S. 1900b. Paleontological notes, no. VI. On supposed merostomatous and other Paleozoic arthropod trails, with notes on those of Limulus. Proceedings of the American Academy of Arts and Sciences, 36, pp. 63-71. https://doi.org/10.2307/20020968

Pemberton, S.G. and Frey, R.W. 1982. Trace fossil nomenclature and the Planolites-Palaeophycus dilemma. Journal of Paleontology, 56, pp. 843-881.

Perrier, V. and Charbonnier, S. 2014. The Montceau-lesMines Largerstätte (Late Carboniferous, France). Comptes Rendus Palevol, 13, pp. 353-367. https://doi. org/10.1016/j.crpv.2014.03.002

Pickerill, R.K. 1992. Carboniferous nonmarine invertebrate ichnocoenoces from southern New Brunswick, eastern Canada. Ichnos, 2, pp. 21-35. https://doi. org/10.1080/10420949209380072

Pickerill, R.K. and Peel, J.S. 1991. Gordia nodosa isp. nov. and other trace fossils from the Cass Fjord Formation (Cambrian) of North Greenland. Rapport Grønlands Geologiske Undersogelse, 150, pp. 15-28.

Pollard, J.E. and Hardy, P.G. 1991. Trace fossils from the Westphalian D of Writhlington Geological Nature Reserve, nr. Radstock, Avon. Proceedings of the Geologists' Association, 102, pp. 169-178.

Prescott, Z.M., Stimson, M.R., Dafoe, L.T., Gibling, M.R., MacRae, R.A., Calder, J.H., and Hebert, B.L. 2014. Microbial mats and ichnofauna of a fluvialtidal channel in the lower Pennsylvanian Joggins Formation, Canada. Palaios, 29, pp. 624-645. https:// doi.org/10.2110/palo.2013.073
Rasband, W.S. 1997-2014. ImageJ: U.S. National Institutes of Health, Bethesda, Maryland, USA. URL < http:// imagej.nih.gov/ij/> March 2015.

Richter, R. 1937. Marken und Spuren aus allen Zeiten. Seckenbergiana, 19, pp. 150-169.

Rindsberg, A. 1994. Ichnology of the Upper Mississippian Hartselle sandstone of Alabama with notes on other Carboniferous formations. Geological Survey of Alabama Bulletin, 158, pp. 1-107.

Rindsberg, A. 2005. Gas-escape structures and their paleoenvironmental significance at the Steven C. Minkin Paleozoic footprint site (Early Pennsylvanian, Alabama). Alabama Paleontological Society Monograph, 1, pp. 177-183.

Ryan, R.J. 1986. Fossil myriapod trails in the PermoCarboniferous strata of northern Nova Scotia, Canada. Maritime Sediments and Atlantic Geology, 22, pp. 156-161. https://doi.org/10.4138/1604

Sadler, C.J. 1993. Arthropod trace fossils from the Permian De Chelly sandstone, northeastern Arizona. Journal of Paleontology, 67, pp. 240-249. https://doi.org/10.1017/ S0022336000032169

Schlirf M., Uchman, A., and Kümmel, M. 2001. Upper Triassic (Keuper) non-marine trace fossils from the Hassberge area (Franconia, southeastern Germany). Paläontologische Zeitschrift, 75, pp. 71-96. https://doi. org/10.1007/BF03022599

Schneider, J.W., Lucas, S.G., Werneburg, R., and Rössler, R. 2010. Euramerican Late Pennsylvanian/Early Permian arthropleurid/tetrapod associations-implications for the habitat and paleobiology of the largest terrestrial arthropod. Carb-Permian transition in Ca-on del Cobre. New Mexico Museum of Natural History and Science Bulletin, no. 49, pp. 49-70.

Seilacher, A. 1953. Studien zur Palichnologie I. Über die methoden der palichnologie. Neues Jahrbuch für Geologie und Paläontologie. Abhandlungen, 96, pp. 421-452.

Seilacher, A., and Seilacher, E. 1994. Bivalvian trace fossils: a lesson from actuopalaeontology. Courier Forschungsinstitut Institut Senckenberg, 169, pp. 5-15.

Shaler, N.S., Woodworth, J.B., and Foerste, A.F. 1899. Geology of the Narragansett Basin. United States Geological Survey Monograph, 3, pp. 1-402. https:// doi.org/10.5962/bhl.title.66965

Skehan, J.W. and Murray, D.P. (Editors). 1978. The coalbearing Narragansett Basin of Massachusetts and Rhode Island, vol. 1, geology. Weston Observatory, Department of Geology and Geophysics, Boston College, Weston, Massachusetts. $112 \mathrm{p}$.

Skehan, J.W., Murray, D.P., Hepburn, J.C., Billings, M.P., Lyons, P.C., and Doyle, R.G. 1979. The Mississippian and Pennsylvanian (Carboniferous) systems in the UnitedStates- Massachusetts, RhodeIsland,andMaine. U.S. Geological Society Professional Paper, 110A, pp. A1-A30. 
Smith, A., Braddy, S.J., Marriott, S.B., and Briggs, D.E.G. 2003. Arthropod trackways from the early Devonian of south Wales: a functional analysis of producers and their behaviour. Geological Magazine, 140, pp. 63-72. https://doi.org/10.1017/S0016756802006982

Smith, J. 1909. Upland fauna of the Old Red Sandstone Formation of Carrick, Ayrshire. A. W. Cross, Kilwinning, Scotland. $41 \mathrm{p}$.

Sproule, R. and Getty, P.R. 2012. Stephanian tetrapod ichnofossils and a triplosobid wing from the Narragansett Basin of Attleboro, Massachusetts, USA. Geological Society of America Abstracts with Programs, Northeastern Section, 44, p. 92.

Sturm, H. 1955. Beiträge zur Ethologie einiger mitteldeutscher Machiliden. Zeitschrift für Tierpsychologie, 12, pp. 337-363. https://doi.org/10.1111/j.1439-0310. 1955.tb01532.x

Tasch, P. 1964. Conchostracan trails in bottom clay muds and on turbid water surfaces. Transactions of the Kansas Academy of Science, 67, pp. 126-128. https:// doi.org/10.2307/3626685

Thompson, M.D. and Hermes, O.D. 2003. Early rifting in the Narragansett Basin, Massachusetts-Rhode Island: evidence from Late Devonian bimodal volcanic rocks. Journal of Geology, 111, pp. 597-604. https://doi. org/10.1086/376768

Towe, K.M. 1959. Petrology and source sediments in the Narragansett Basin of Rhode Island and Massachusetts. Journal of Sedimentary Petrology, 29, pp. 503-512.

Trewin, N. H. and McNamara, K.J. 1994. Arthropods invade the land: trace fossils and paleoenvironments of the Tumblagooda Sandstone (late Silurian) of Kalbarri, western Australia. Transactions of the Royal Society of Edinburgh: Earth Sciences, 85, pp. 177-210. https:// doi.org/10.1017/S026359330000359X

Uchman, A., Kazakauskas, V., and Gaigalas, A. 2009. Trace fossils from Late Pleistocene varved lacustrine sediments in eastern Lithuania. Palaeogeography, Palaeoclimatology, Palaeoecology, 272, pp. 199-211. https://doi.org/10.1016/j.palaeo.2008.08.003

Voigt, E., and Hartmann, G. 1970. Über rezente vergipste Ostracodfärten. Senckenbergiana Maritima, 2, pp. 102-118.
Voigt, S., Lucas, S.G., and Krainer, K. 2013. Coastalplain origin of trace-fossil bearing red beds in the Early Permian of southern New Mexico, U.S.A. Palaeogeography, Palaeoclimatology, Palaeoecology, 369, pp. 323-334. https://doi.org/10.1016/j. palaeo.2012.10.041

Wagner, R.H. and Lyons, P.C. 1997. A critical analysis of the higher Pennsylvanian megafloras of the Appalachian region. Review of Palaeobotany and Palynology, 95, pp. 255-283. https://doi.org/10.1016/S00346667(96)00037-1

Walcott, C.D. 1890. Descriptive notes of new genera and species from the Lower Cambrian or Olenellus Zone of North America. Proceedings of the United States National Museum, 12, pp. 33-46. https://doi. org/10.5479/si.00963801.763.33

Walker, E.F. 1985. Arthropod ichnofauna of the Old Red Sandstone at Dunure and Montrose, Scotland. Transactions of the Royal Society of Edinburgh: Earth Sciences, 76, pp. 287-297. https://doi.org/10.1017/ S0263593300010506

Walter, H. and Gaitzsch, B. 1988. Beiträge zur Ichnologie limnisch-terrestrischer Sedimentationsräume Teil II: Diplichnites minimus n. ichnosp. aus dem Permosiles des flechtinger Höhenzuges. Freiberger Forschungsheft, C427, pp. 73-84.

Whyte, M.A. and Romano, M. 2001. A dinosaur ichnocoenosis from the Middle Jurassic of Yorkshire, UK. Ichnos, 8, pp. 223-234. https://doi. org/10.1080/10420940109380189

Willard, B. and Cleaves, A.B. 1930. Amphibian footprints from the Pennsylvanian of the Narragansett Basin. Bulletin of the Geological Society of America, 41, pp. 321-327. https://doi.org/10.1130/GSAB-41-321

Woodworth, J.B. 1900. Vertebrate footprints on Carboniferous shales of Plainville, Massachusetts. Bulletin of the Geological Society of America, 11, pp. 449-454. https://doi.org/10.1130/GSAB-11-449

Zen, E-an, Goldsmith, R., Ratcliffe, N.M., Robinson, P., Stanley, R.S., Hatch, N.L., Shride, A.F., Weed, E.G.A., and Wones, D.R. 1983. Bedrock geologic map of Massachusetts. The Commonwealth of Massachusetts, Department of Public Works, scale 1:250 000. 
APPENDIX A

\section{Names of ichnotaxa used in text with authorpships}

Acripes Matthew 1910

Acripes incertipes Matthew 1910

Batrachichnus Woodworth 1900

Cardinichnus Benner et al. 2015

Cardinichnus ottawensis Mángano et al. 1997

Characichnos Whyte and Romano 2001

Cochlichnus Hitchcock 1858

Cochlichnus anguineus Hitchcock 1858

Dendroidichnites Demathieu et al. 1992

Dendroidichnites irregulare Demathieu et al. 1992

Diplichnites Dawson 1873

Diplichnites aenigma Dawson 1873

Diplichnites cuithensis Briggs et al. 1979

Diplichnites gouldi Gevers et al. 1971

Diplichnites triassicus Linck 1943

Diplopodichnus Brady 1947

Diplopodichnus biformis Brady 1947

Haplotichnus Miller 1889

Haplotichnus indianensis Miller 1889

Helminthoidichnites Fitch 1850

Helminthoidichnites tenuis Fitch 1850

Helminthopsis Heer 1877

Gordia Emmons 1844

Gordia arcuata Ksiazkiewicz 1977

Gordia carickensis Smith 1909

Gordia marina Emmons 1844

Gordia nodosa Pickerill and Peel 1991

Lockeia James 1879

Lockeia siliquaria James 1879
Mermia Smith 1909

Mitchellichnus Walker 1985

Mitchellichnus cf. ferrydenensis Walker 1985

Narragansettichnus Getty et al. 2017 (this study)

Narragansettichnus fortunatus Getty et al. 2017 (this study)

Palaeophycus Hall 1847

Paleohelcura Gilmore 1926

Paleohelcura tridactyla Gilmore 1926

Planolites Nicholson 1873

Planolites annularis Walcott 1890

Planolites beverleyensis Billings 1862

Planolites montanus Richter 1937

Siskemia Smith 1909

Siskemia bipediculus Smith 1909

Siskemia elegans Smith 1909

Siskemia lata-via Smith 1909

Stiallia Smith 1909

Stiallia berriana Smith 1909

Stiallia pilosa Smith 1909

Stiaria Smith 1909

Stiaria intermedia Smith 1909

Tonganoxichnus Mángano et al. 1997

Tonganoxichnus apacheensis Braddy and Briggs 2002

Tonganoxichnus buildexensis Mángano et al. 1997

Tonganoxichnus robledoensis Braddy and Briggs 2002

Treptichnus Miller 1889

Treptichnus bifurcus Miller 1889

Undichna Anderson 1976

Undichna unisulca de Gilbert et al. 1999

\section{APPENDIX B}

\section{Registration of new nomenclatural acts}

We document below the registration of the new names occurring in the present work (urn:lsid:zoobank.org:pub:EE70CD325E92-4368-A07C-5D04B408E7155D04B408E715), in accordance with revisions to the International Code of Zoological Nomenclature (2012) that permit online publication of new taxa provided that registration of the new names is documented within the work in which they appear:

Narragansettichnus Getty, Sproule, Stimson, and Lyons, new ichnogenus

Zoobank LSID: urn:lsid:zoobank.org:act:D774FD43-73B7-4A82-B741-C529CFA8273F

Narragansettichnus fortunatus Getty, Sproule, Stimson, and Lyons, new ichnospecies

Zoobank LSID: urn:lsid:zoobank.org:act:4A5B8E78-EFB5-491F-83CA-9D7C197C712F

Editorial responsibility: Robert A. Fensome 